\title{
KAJIAN KARAKTERISTIK KORIDOR JALAN SLAMET RIYADI SEBAGAI RUANG INTERAKSI SOSIAL KOTA SURAKARTA BERDASARKAN TEORI GOOD CITY FORM
}

\author{
Silka Azzahra Shafa Aulia ${ }^{1}$, Galing Yudana ${ }^{1}$, Istijabatul Aliyah 1 \\ ${ }_{1}^{1}$ Program Studi Perencanaan Wilayah dan Kota, Fakultas Teknik, Universitas Sebelas Maret
}

\begin{abstract}
Abstrak
Koridor Jalan Slamet Riyadi yang berada di pusat Kota Surakarta terjadi perkembangan aktivitas perkotaan juga berfungsi sebagai ruang interaksi sosial. Penelitian ini bertujuan untuk mengetahui karakteristik Koridor Jalan Slamet Riyadi sebagai ruang interaksi sosial Kota Surakarta berdasarkan Teori Good City Form. Menggunakan jenis penelitian deskriptif kualitatif untuk mengeksplorasi isu dengan pendeskripsian secara detail sehingga didapatkan gambaran mendalam tentang karakteristik koridor jalan berdasarkan Teori Good City Form di lokasi terkait. Pendekatan penelitian dilakukan secara deduktif dengan peneliti akan melakukan penelitian berangkat dari teori mengenai koridor, aktivitas di ruang publik, dan Teori Good City Form untuk terjun ke lapangan melakukan pencarian data yang dibutuhkan. Koridor Jalan Slamet Riyadi memenuhi kriteria bentuk yang baik sebagai ruang interaksi Kota Surakarta berdasarkan Teori Good City Form, juga memiliki karakteristik fisik (physical characteristic) dan karakteristik spasial (spatial characteristic) yang berbeda dari jalan perkotaan lainnya. Karakteristik fisik berupa jalan besar yang membelah pusat Kota Surakarta dengan pembagian jalur lalu lintas yang beragam mulai dari jalur lambat untuk becak dan sepeda, jalur kendaraan bermotor berdampingan dengan rel kereta api aktif, dan citywalk sebagai jalur pejalan kaki dengan dilengkapi deretan bangunan untuk perdagangan dan jasa serta pepohonan rindang. Sedangkan karakteristik spasial berupa jalan perkotaan yang memiliki nilai sejarah diantaranya sebagai pembatas daerah kekuasaan antara Keraton Kasunanan dan Keraton Mangkunegaran serta memiliki peranan sangat penting bagi Kota Surakarta selain sebagai penghubung menuju pusat Kota Surakarta, juga menjadi wadah penyelenggaraan beragam aktivitas bagi masyarakat juga event tahunan Kota Surakarta.
\end{abstract}

Kata kunci: karakteristik; koridor Jalan Slamet Riyadi; ruang interaksi sosial; Teori Good City Form

\begin{abstract}
The Slamet Riyadi Street Corridor in the center of Surakarta City develops urban activities and also functions as a space for social interaction. This research aims to determine the characteristics of The Slamet Riyadi Street Corridor as a space for social interaction in Surakarta based on the Good City Form Theory. This research applies qualitative method with in-depth overview regarding the characteristics of the road corridor based on the Good City Form Theory. . Moreover, deductive approach is implemented in which the researcher departs from the certain theory as such as theory on corridors, activities in public spaces, and Good City Form before going to the field searching for the data. The results reveal that the Slamet Riyadi Street Corridor fulfills a good form criteria as Surakarta's space for social interaction based on the Good City Form Theory. It also has the physical and spatial characteristics that are different from other urban roads. Physical characteristics are in the form of a large road that divides the center of the city of Surakarta by the distribution of diverse traffic lanes ranging from slow lanes to tricycles and bicycles, motorized vehicle lanes adjacent to active railroads, and citywalk as a pedestrian lane equipped with a row of buildings for trade and services and shady trees. Whereas, for spatial characteristics, the street has historical values include functioning as a boundary between the Kasunanan Palace and the Mangkunegaran Palace andserving as a link of Surakarta's peri-urban to the center of the Surakarta City, as well asbecoming a place for organizing various activities for the community as well as the annual event of the Surakarta City.
\end{abstract}

Keywords: characteristics; Slamet Riyadi Street corridor; space for social interaction; Good City Form theory

\section{PENDAHULUAN}

Kota merupakan suatu wilayah yang menjadi pusat ekonomi dan pusat pelayanan umum dengan struktur dan tata ruang perkotaan seperti adanya jalur jalan dan ruang-ruang perkotaan yang nyata. Max Weber dalam Nas (1979) menyebutkan suatu daerah dapat disebut kota apabila penghuni setempatnya dapat memenuhi sebagian besar kebutuhan ekonominya di pasar lokal. Kota Surakarta sebagai salah satu kota yang berada di Provinsi Jawa Tengah telah mengalami pertumbuhan dan perkembangan yang sangat pesat. Pertumbuhan kota bertujuan pada berbagai 
peran yang saling bersaing yang perlu dipenuhi oleh ruang publik diantaranya sebagai ruang pertemuan, sebagai domain publik, sebagai ruang politik dan layak huni, dan sebagai ruang untuk perdagangan (Agyeman \& Zavetoski, 2015; Brenner, Marcuse \& Mayer, 2012; Hajer \& Reijindorp, 2001). Menurut Pontoh dan Setiawan, unsur pembentuk struktur tata ruang kota terdiri dari pusat kegiatan, kawasan fungsional, dan jaringan jalan (Pontoh \& Setiawan, 2008). Jalan adalah ruang publik sosial utama di kota (Mehta, 2013). Jalan memiliki peran sebagai sebuah ruang publik kota sebagaimana Spiro Kostof berpendapat bahwa satu-satunya legitimasi jalan yaitu sebagai ruang publik (Kostof, 1992). Hal ini juga sependapat dengan Jacobs bahwa jalan, trotoar, dan tempat-tempat umum utama sebuah kota merupakan organ yang paling vital (Jacobs J. , 1961).

Jalan perkotaan adalah jenis ruang publik yang sangat khusus serta sebagai fungsi mobilitas merupakan saluran utama untuk memfasilitasi arus manusia dan barang yang memasuki kota, meskipun juga memenuhi beberapa fungsi lainnya sebagai tempat umum (Mehta, 2013). Agyeman dan Zavetovski berpendapat bahwa jalan tidak hanya fasilitas fisik dan material yang berfungsi untuk pergerakan orang dan barang, tetapi juga sebagai ruang sosial dan simbol yang signifikan di mana pengguna terkait dengan sistem ekonomi, transportasi, makanan, budaya, sejarah, dan pemerintahan yang saling berhubungan, serta di dalamnya terdapat interaksi antar individu, kelompok dan komunitas (Agyeman \& Zavetoski, 2015). Jalan-jalan perkotaan harus direncanakan sebagai tempat untuk mengakomodir mobilitas dan ruang publik, sehingga memungkinkan pergerakan dengan moda transportasi yang berbeda serta keberlangsungan interaksi sosial, bersantai, dan rekreasi. Singkatnya, jalan-jalan perkotaan dapat menyeimbangkan antara mobilitas dan imobilitas (Nikolaeva, 2012; Bertolini, 2012; Bertolini \& Dijst, 2003). Ditambahkan oleh Jacobs, bahwa jalan yang baik mendorong partisipasi, masyarakat berhenti untuk berbicara atau mungkin mereka duduk dan melihat (Jacobs A. B., 1993).

Jalan Slamet Riyadi merupakan jalan utama Kota Surakarta dengan fungsi jalan arteri sekunder dan strategis dalam pergerakan manusia dan barang. Jalan perkotaan terlihat dari adanya keragaman penggunaan yang paling kompleks dan letaknya yang saling berdekatan (Jacobs J. , 1961). Pada sepanjang jalan terdapat aktivitas perdagangan dan jasa yang terus berlanjut dari zaman kolonial hingga sekarang. Saat ini terlihat aktivitas perdagangan dan jasa berupa deretan pertokoan, perbankan, hotel, tempat perbelanjaan, dan sarana rekreasi. Seperti yang terjadi di sepanjang Koridor Jalan Slamet Riyadi yang menjadi wadah penyelenggaraan beragam aktivitas bagi masyarakat Kota Surakarta. Koridor jalan ini juga menjadi pintu masuk Kota Surakarta yang menghubungkan hingga ke pusat kota (Kawasan Gladag). Ditandai dengan keberadaan Stasiun Purwosari yang merupakan stasiun tertua di Kota Surakarta didirikan tahun 1875 sebagai stasiun transit pertama bagi tamu-tamu kerajaan yang dikelola oleh pihak maskapai kereta api swasta atau saat itu dikenal dengan Nederlandsch Indische Spoorweg Mij (NISM) yang berada di Semarang yang menghubungkan antara Semarang - Solo - Yogyakarta (Shiraishi, 1997). Stasiun Purwosari berada di wilayah Keraton Mangkunegaran (P.2101 Koleksi Arsip Rekso Pustoko Pura Mangkunegaran). Koridor jalan ini juga berfungsi sebagai ruang interaksi sosial di pusat Kota Surakarta seperti Solo Car Free Day (CFD), Solo Batik Carnival, Solo Menari, Solo Run $10 \mathrm{~K}$, dan event tahunan Kota Surakarta lainnya yang menjadikan Jalan Slamet Riyadi memiliki nilai yang sangat penting bagi Kota Surakarta. Adanya keselarasan antara aktivitas dan kondisi fisik masyarakat dengan bentuk serta ruang yang mewadahinya menimbulkan suatu karakteristik (Lynch, 1981). Hal ini perlu diamati berdasarkan teori Kevin Lynch yaitu Teori Good City Form. Oleh karena itu penelitian ini bertujuan untuk mengetahui karakteristik Koridor Jalan Slamet Riyadi sebagai ruang interaksi sosial Kota Surakarta berdasarkan Teori Good City Form. Penelitian ini diharapkan mampu memberikan manfaat berupa informasi gambaran mengenai karakteristik Koridor Jalan Slamet Riyadi sebagai ruang interaksi sosial Kota Surakarta berdasarkan Teori Good City Form sehingga bagi stakeholder terkait baik Pemerintah Kota Surakarta, maupun pihak swasta dapat mengambil langkah-langkah dalam menjaga dan meningkatkan kualitas Jalan Slamet Riyadi. Informasi ini juga dapat dijadikan pertimbangan dalam melakukan evaluasi mengenai peningkatan penggunaan, fungsi, dan kinerja Jalan Slamet Riyadi ke arah yang lebih progresif. Selain itu, penelitian ini juga diharapkan dapat memberikan masukan bahan literatur untuk dijadikan referensi bagi penelitian selanjutnya.

\section{KAJIAN PUSTAKA}

\subsection{KORIDOR}

Koridor adalah lahan memanjang yang membelah kota/kawasan atau sebuah lorong membentuk fasade bangunan berderet dengan lantai atau ruang kota untuk bergerak dari ruang satu ke ruang lainnya (Wiharnanto dalam Sumartono, 2003). Koridor adalah jalan yang dibentuk oleh dua deretan massa (bangunan atau pohon) yang membentuk sebuah ruang untuk menghubungkan dua kawasan atau wilayah kota (Zahnd, 1999). Bentuk koridor adalah ruang terbuka dengan bentuk memanjang yang memiliki batas-batas di sisinya (Krier, 1979). Koridor berbentuk deretan massa yang 
menciptakan linkage visual antara dua tempat (Bacon, 1967). Trancik menyebutkan bahwa pola massa dalam sebuah koridor adalah suatu figure ground ini dapat membantu untuk mengidentifikasikan sebuah tekstur dan pola tata ruang (Trancik, 1986). Suatu koridor tidak sekedar ruang sirkulasi, namun lebih jauh merupakan ruang aktivitas masyarakat (Project for Public Spaces, 2008). Koridor berfungsi sebagai jalan sekaligus wadah berinteraksi (Kurokawa, 1997).

\subsection{AKTIVITAS DI RUANG PUBLIK}

Menurut Spurrier dalam Bishop, jalan tidak dapat dipertimbangkan hanya sebagai jalur kendaraan, tetapi secara keseluruhan menjadi bagian integral kehidupan manusia (Bishop, 1989). Budiharjo mengatakan bila jalan direncanakan hanya berdasarkan anggapan akan fungsinya, maka akan menutup peluang untuk memanfaatkan jalan sebagai ruang untuk beraktivitas (Budiharjo \& Sujarto, 2005). Ruang terbuka baik berupa lapangan maupun koridor/jaringan, merupakan salah satu elemen rancang kota yang sangat penting dalam pengendalian kualitas lingkungan ekologis dan sosial (Shirvani, 1985). Ruang publik juga bermanfaat untuk melayani kebutuhan masyarakat sebagai sarana rekreatif maupun sebagai tempat untuk melakukan interaksi sosial dalam kehidupan masyarakat. Ditambahkan oleh Jacobs bahwa jalan yang baik mendorong partisipasi, masyarakat berhenti untuk berbicara atau mungkin mereka duduk dan melihat (Jacobs A. B., 1993). Keberadaan aktifitas dalam ruang publik kota dapat dibagi dalam dua kategori meliputi (Gehl \& Gemzoe, 1996): a) kelompok informal dan event-event dalam skala kecil seperti pertunjukan musisi jalanan; dan b) event-event yang diselenggarakan dalam skala yang lebih besar, pertunjukan yang memerlukan persiapan seperti festival dan aktivitas-aktivitas kebudayaan yang menggunakan ruang publik sebagai wadah aktivitasnya. Pertunjukan dan aktivitas kebudayaan tersebut adalah atraksi yang menarik untuk ruang publik kota dan akan menjadi magnet tersendiri sehingga mengundang pengunjung dalam jumlah yang sangat besar untuk menikmatinya. Aktivitas-aktivitas ini menjadikan ruang publik kota menarik, amusing dan tak terduga.

\subsection{GOOD CITY FORM}

Suatu kota dapat dikatakan memiliki bentuk yang baik apabila memiliki lingkungan dengan karakteristik fisik (physical characteristic) dan karakteristik spasial (spatial characteristic) yang berbeda dengan kota lain. Karakteristik fisik kota paling mudah dikenali sebab dapat diamati secara langsung berkaitan dengan kenampakan suatu tempat; sedangkan karakteristik spasial kota berkaitan mengenai sebuah ruang yang dipengaruhi oleh suasana sehingga dapat dirasakan, memiliki peranan namun tidak terdefinisikan dengan jelas. Kejelasan emosional suatu kota yang dapat dirasakan secara jelas oleh warga kotanya atau dikenal dengan urban legibility. Urban legibility dapat dipengaruhi kualitas visual suatu kota serta kemampuan mudah ditemui dan dikenali. Berdasarkan Teori Good City Form (Lynch, 1981), Lynch menjelaskan bahwa suatu kota dapat dikatakan memiliki bentuk yang baik, apabila kota tersebut memenuhi dimensi diantaranya: a) Vitality, dimensi vitality mengandung arti bahwa kota beserta isinya mempunyai kemampuan untuk memenuhi kebutuhan vital warga kota, serta terdistribusi secara tepat guna (efficiency) dan berkeadilan (justice); b) Sense, dimensi sense diartikan sebagai kemudahan pengguna ruang atau warga kota mengenali ruang kota yang ingin dimanfaatkan. Ruang yang memiliki sense yang baik harus selaras dengan kegiatan didalamnya, sehingga siapapun pengguna ruang memperoleh makna tertentu setelah melakukan aktivitas (efficient dan justice). Kepekaan rasa (sense) ini muncul apabila telah terjalin suatu interaksi antara warga kota tersebut dengan ruang yang dimanfaatkan; c) Fit, dimensi fit adalah kesesuaian aktivitas warga kota dengan kondisi ruang kota yang menampung atau mewadahi kegiatan, serta ruang tersebut juga diharapkan tepat guna dan berkeadilan bagi pengguna; d) Accessibility, dimensi accessibility menekankan kemudahan warga mengakses ruang yang menampung kegiatannya. Akses yang baik apabila semua pengguna ruang mampu menjangkau tempat aktivitas, baik dari segi biaya maupun waktu (efficient dan justice); dan e) Control, dimensi control diwujudkankan dengan keberadaan regulasi mengenai keberlanjutan fisik ruang kota serta pengguna. Regulasi yang baik memberi kemudahan kepada pengguna tanpa mengurangi aspek pelestarian ruang, bersesuaian dengan fungsi ruang, serta berlaku untuk setiap pengguna ruang (efficient dan justice).

\section{METODE PENELITIAN}

Pendekatan penelitian ini dilakukan secara deduktif yaitu dengan menempatkan masalah dalam kerangka berpikir teoritis (theoretical framework). Peneliti akan melakukan penelitian dengan berangkat dari teori untuk terjun ke lapangan dalam melakukan pencarian data yang dibutuhkan. Teori yang ada yaitu mengenai koridor, aktivitas di ruang publik, dan Teori Good City Form yang kemudian diintepretasi menghasilkan komponen penelitian dan data untuk dicari di lapangan. Penelitian ini menggunakan jenis penelitian deskriptif kualitatif karena peneliti ingin mengeksplorasi isu mengenai karakteristik koridor Jalan Slamet Riyadi Kota Surakarta sebagai ruang interaksi sosial Kota Surakarta berdasarkan Teori Good City Form dengan pendeskripsian secara detail sehingga dapat menyediakan gambaran 
mendalam tentang karakteristik koridor jalan berdasarkan Teori Good City Form yang ada di lokasi terkait. Penelitian kualitatif adalah penelitian yang digunakan untuk mendeskripsikan dan menganalisis fenomena, peristiwa, aktivitas sosial, sikap, kepercayaan, presepsi, dan orang secara individual maupun kelompok (Sukmadinata, 2009). Untuk mendeksripsikan dan menginterpretasikan fenomena baik alamiah maupun buatan manusia tersebut, guna memperoleh informasi mengenai bentuk, aktivitas, karakteristik, perubahan, hubungan, kesamaan, dan perbedaan antara fenomena yang satu dengan fenomena lainnya, maka oleh Sukmadinata dalam (Linarwati, Fathoni, \& Minarsih, 2016) disebutkan perlunya penelitian yang bersifat deskriptif. Berikut adalah komponen penelitian, indikator penelitian, dan definisi operasional dalam penelitian ini (lihat Tabel 1).

Tabel 1. Komponen Penelitian, Indikator Penelitian, Definisi Operasional, dan Teknik Pengumpulan Data

\begin{tabular}{|c|c|c|c|c|}
\hline No. & $\begin{array}{l}\text { Komponen } \\
\text { Penelitian }\end{array}$ & $\begin{array}{l}\text { Indikator } \\
\text { Penelitian }\end{array}$ & Definisi Operasional & Teknik Pengumpulan Data \\
\hline 1 & $\begin{array}{l}\text { Kondisi } \\
\text { Eksisting } \\
\text { Koridor } \\
\text { Jalan Slamet } \\
\text { Riyadi }\end{array}$ & $\begin{array}{l}\text { Kondisi fisik } \\
\text { Koridor Jalan } \\
\text { Slamet Riyadi, } \\
\text { meliputi: } \\
\text { - Jenis Guna } \\
\text { Lahan } \\
\text { - Kelengkapan di } \\
\text { Koridor Jalan } \\
\text { Slamet Riyadi } \\
\text { - Fasade dan } \\
\text { Massa Bangunan }\end{array}$ & $\begin{array}{l}\text { Jenis penggunaan lahan terbagi lahan } \\
\text { terbangun (perumahan, industri, } \\
\text { perdagangan, jasa, perkantoran, dan } \\
\text { sebagainya) dan lahan tak terbangun } \\
\text { (rekreasi, transportasi, ruang terbuka, } \\
\text { dan sebagainya). } \\
\text { Kelengkapan di Koridor Jalan Slamet } \\
\text { Riyadi berupa jaringan jalan, jalur } \\
\text { pedestrian, ruang terbuka berbentuk } \\
\text { linier, dan ruang parkir. } \\
\text { Fasade bangunan yaitu wajah suatu } \\
\text { bangunan atau tampak depan suatu } \\
\text { bangunan yang dapat memberikan } \\
\text { suatu karakter, kesan, keunikan dan } \\
\text { keindahan dari bangunan tersebut. } \\
\text { Sedangkan massa bangunan berkaitan } \\
\text { dengan fungsi bangunan, jenis } \\
\text { bangunan, ketinggian bangunan, dan } \\
\text { Koefisien Lantai Bangunan (KLB). }\end{array}$ & $\begin{array}{l}\text { Peneliti melakukan observasi langsung } \\
\text { ke lapangan membawa peta persil } \\
\text { bangunan-bangunan di sepanjang } \\
\text { Koridor Jalan Slamet Riyadi untuk } \\
\text { mendata nama bangunan, jenis guna } \\
\text { lahan, serta jumlah lantai setiap persil } \\
\text { bangunan. Sekaligus mengamati, } \\
\text { mendata, dan mencatat letak mengenai } \\
\text { kelengkapan Koridor Jalan Slamet } \\
\text { Riyadi. Diambil pula foto-foto sebagai } \\
\text { dokumentasi saat observasi } \\
\text { berlangsung. Selain itu, diperlukan juga } \\
\text { data-data terkait dengan Koridor Jalan } \\
\text { Slamet Riyadi dari studi literatur dan } \\
\text { dinas terkait seperti Dinas Lingkungan } \\
\text { Hidup, Dinas Pekerjaan Umum dan } \\
\text { Penataan Ruang, dan sebagainya. }\end{array}$ \\
\hline 2 & $\begin{array}{l}\text { Kondisi } \\
\text { Interaksi } \\
\text { Sosial Kota } \\
\text { Surakarta }\end{array}$ & $\begin{array}{l}\text { Beragam aktivitas } \\
\text { sosial, dan budaya } \\
\text { masyarakat di } \\
\text { Koridor Jalan } \\
\text { Slamet Riyadi. }\end{array}$ & $\begin{array}{l}\text { Aktivitas masyarakat yang terjadi di } \\
\text { koridor meliputi aktivitas sosial, dan } \\
\text { aktivitas budaya, serta pihak yang } \\
\text { terlibat dalam aktivitas di koridor Jalan } \\
\text { Slamet Riyadi }\end{array}$ & $\begin{array}{l}\text { Peneliti melakukan wawancara secara } \\
\text { langsung kepada pelaku aktivitas di } \\
\text { Koridor Jalan Slamet Riyadi yang } \\
\text { dikelompokkan menjadi: pelaku } \\
\text { ekonomi, masyarakat, dan pengunjung. } \\
\text { Data-data juga dikumpulkan melalui } \\
\text { studi literatur dari data tertulis atau } \\
\text { dokumen yang sudah disusun oleh } \\
\text { instansi pemerintahan, buku sejarah, } \\
\text { atau hasil penelitian yang sebelumnya. } \\
\text { Diambil pula foto-foto sebagai } \\
\text { dokumentasi saat survei ke lapangan } \\
\text { berlangsung serta saat event-event } \\
\text { sosial dan budaya masyarakat } \\
\text { berlangsung di Koridor Jalan Slamet } \\
\text { Riyadi. }\end{array}$ \\
\hline
\end{tabular}

Tabel 2. Batasan Narasumber Penelitian

\begin{tabular}{|c|c|c|c|c|}
\hline No. & Narasumber & $\begin{array}{l}\text { Teknik Pengambilan } \\
\text { Sampel }\end{array}$ & $\begin{array}{l}\text { Jumlah Sampel } \\
\text { (orang) }\end{array}$ & Keterangan \\
\hline 1. & Pelaku Ekonomi & & 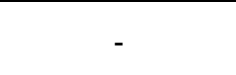 & $\begin{array}{l}\text { Pelaku ekonomi adalah pelaku aktivitas ekonomi di } \\
\text { Koridor Jalan Slamet Rivadi }\end{array}$ \\
\hline 2. & Masyarakat & Purposive Sampling & - & $\begin{array}{l}\text { Masyarakat adalah pelaku aktivitas harian di Koridor } \\
\text { Jalan Slamet Riyadi } \\
\text { Pengunjung merupakan orang yang berkunjung ke }\end{array}$ \\
\hline 3. & Pengunjung & Accidental Sampling & - & $\begin{array}{l}\text { Koridor Jalan Slamet Riyadi untuk melakukan aktivitas } \\
\text { pada saat-saat tertentu. }\end{array}$ \\
\hline
\end{tabular}


Sampel dalam penelitian ini diambil dengan menggunakan teknik purposive sampling dan accidental sampling yang termasuk non probability sampling (lihat Tabel 2). Menurut Sukandarrumidi, pada teknik purposive sampling siapa yang akan diambil sebagai sampel diserahkan pada pertimbangan pengumpul data yang berdasarkan atas pertimbangannya sesuai dengan maksud dan tujuan penelitian (Sukandarrumidi, 2004). Apabila informasi yang didapatkan mulai terjadi pengulangan atau tidak ditemukannya informasi baru atau telah mencapai titik jenuh peneliti, serta informasi yang didapat telah dapat menjawab keseluruhan pertanyaan peneliti, maka penarikan sampel dapat dihentikan. Sedangkan teknik accidental sampling yaitu pengambilan sampel dengan menggunakan metode ini ditujukan untuk pengambilan sampel pada orang- orang yang mudah ditemui atau yang berada pada waktu yang tepat, mudah ditemui dan dijangkau (Widayat, 2004).

\section{HASIL DAN PEMBAHASAN}

\subsection{POSISI KORIDOR JALAN SLAMET RIYADI DALAM KOTA SURAKARTA}

Kota Surakarta merupakan salah satu kota besar di Jawa Tengah yang menunjang kota-kota lainnya seperti Semarang maupun Yogyakarta. Berdasarkan data Badan Pusat Stastistik Kota Surakarta, penduduk Kota Surakarta pada Tahun 2017 mencapai 516.102 jiwa dengan rasio jenis kelamin sebesar 95\% dan tingkat kepadatan penduduk mencapai $11.718,78$ jiwa/ $/ \mathrm{km}^{2}$. Luas wilayah Kota Surakarta mencapai $44,04 \mathrm{~km}^{2}$ yang terbagi dalam 5 kecamatan. Sebagian besar lahan dipakai sebagai tempat pemukiman sebesar $66 \%$, sedangkan untuk kegiatan berkisar antara $17 \%$ dari luas lahan yang ada. Bersama dengan Yogyakarta, Surakarta merupakan pewaris Kesultanan Mataram yang dipecah melalui Perjanjian Giyanti pada Tahun 1755. Jaringan jalan di Kota Surakarta terbagi menjadi 3 menurut fungsinya, yaitu jalan arteri, kolektor, dan lokal.

Peningkatan berbagai aspek ekonomi menuntut peningkatan di bidang tranportasi, khususnya peningkatan jalan. Panjang jalan di wilayah Kota Surakarta pada tahun 2017 mencapai 673,33 kilometer. Jalan arteri primer di Kota Surakarta yaitu Jalan Ahmad Yani, sedangkan salah satu jalan arteri sekunder di Kota Surakarta yaitu Jalan Slamet Riyadi. Jalan Slamet Riyadi merupakan jalan yang membelah pusat Kota Surakarta dengan peranan pelayanan distribusi jasa dan barang untuk masyarakat dalam kota. Jalan arteri dan jalan kolektor di Kota Surakarta menghubungkan area permukiman ke area perkantoran, perdagangan, dan jasa. Area guna lahan permukiman tersebar menyeluruh di wilayah Kota Surakarta, dengan guna lahan perdagangan \& jasa cenderung mengikuti jalan arteri dan kolektor. Persebaran area komersial ini cenderung mengikuti pola jaringan jalan atau linier. Salah satunya terlihat pada Jalan Slamet Riyadi yang memiliki fungsi jalan sebagai jalan arteri sekunder Kota Surakarta yang dapat dilihat pada Gambar 1.

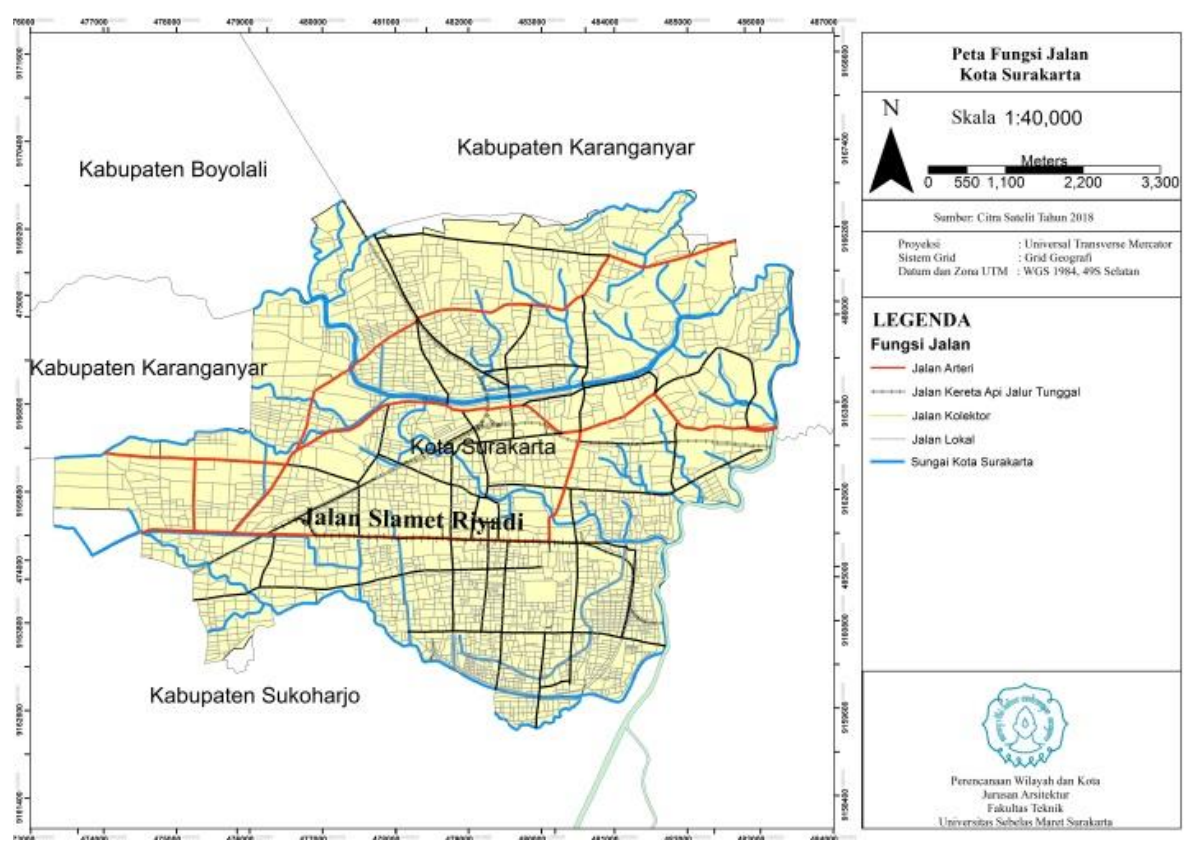

Sumber: BAPPEDA Kota Surakarta, 2018

Gambar 1. Peta Fungsi Jalan Kota Surakarta 
Secara umum, kawasan Jalan Slamet Riyadi merupakan pusat aktivitas bisnis dan perdagangan di Kota Surakarta. Tata guna lahan pada jalur Jalan Slamet Riyadi didominasi oleh perdagangan dan jasa, perkantoran, hotel, serta fasilitas umum lainnya (lihat Gambar 2 dan 3). Sedangkan permukiman tidak begitu jelas terlihat karena berada di dalam blok atau tidak berada tepat di sepanjang koridor Jalan Slamet Riyadi. Hal ini menjadikan Koridor Jalan Slamet Riyadi sebagai area perdagangan dan bisnis. Berdasarkan survei lapangan yang dilakukan, diketahui terdapat 472 buah bangunan yang berada di sepanjang koridor dan 302 buah bangunan di antaranya memiliki fungsi usaha (lihat Tabel 3 ). Bangunan di sepanjang Koridor Jalan Slamet Riyadi berupa bangunan yang bertipologi berjajar memanjang mengikuti bentuk jalan dengan mayoritas bangunan ruko bertingkat menghadap ke jalan. Dari keseluruhan bangunan di Koridor Jalan Slamet Riyadi, mayoritas bangunan dengan jumlah lantai maksimal 2 lantai atau bangunan gedung sederhana. Hanya beberapa bangunan dengan jenis penggunaan untuk pelayanan kesehatan, perhotelan, serta perkantoran dan perbankan yang memiliki jumlah lantai lebih dari 3 lantai (lihat Gambar 4 dan 5). Hal ini sesuai dengan pernyataan bahwa koridor adalah lahan yang memanjang yang membelah kota/kawasan atau sebuah lorong yang membentuk fasade bangunan berderet dengan lantai atau ruang kota untuk bergerak dari ruang satu ke ruang yang lainnya (Wiharmanto dalam Sumartono, 2003).

Tabel 3. Jumlah Fungsi Bangunan

\begin{tabular}{cccc}
\hline Fungsi Bangunan & Jenis Penggunaan & Jumlah (buah) & Koefisien Lantai Bangunan (KLB) \\
\hline Fungsi Hunian & Rumah Tinggal & 24 & $1-3$ \\
Fungsi Keagamaan & Gereja & 3 & 1 \\
Fungsi Usaha & Perkantoran dan perbankan & 45 & $1-9$ \\
& Perdagangan & 243 & $1-3$ \\
Fungsi Sosial dan & Perhotelan & 14 & $2-15$ \\
Budaya & Pelayanan Kesehatan & 4 & $1-10$ \\
& Stasiun & 1 & 1 \\
& Pendidikan & 4 & $1-3$ \\
Fungsi Khusus & Pelayanan Umum & 9 & $1-4$ \\
& Kebudayaan & 8 & $1-2$ \\
\hline
\end{tabular}

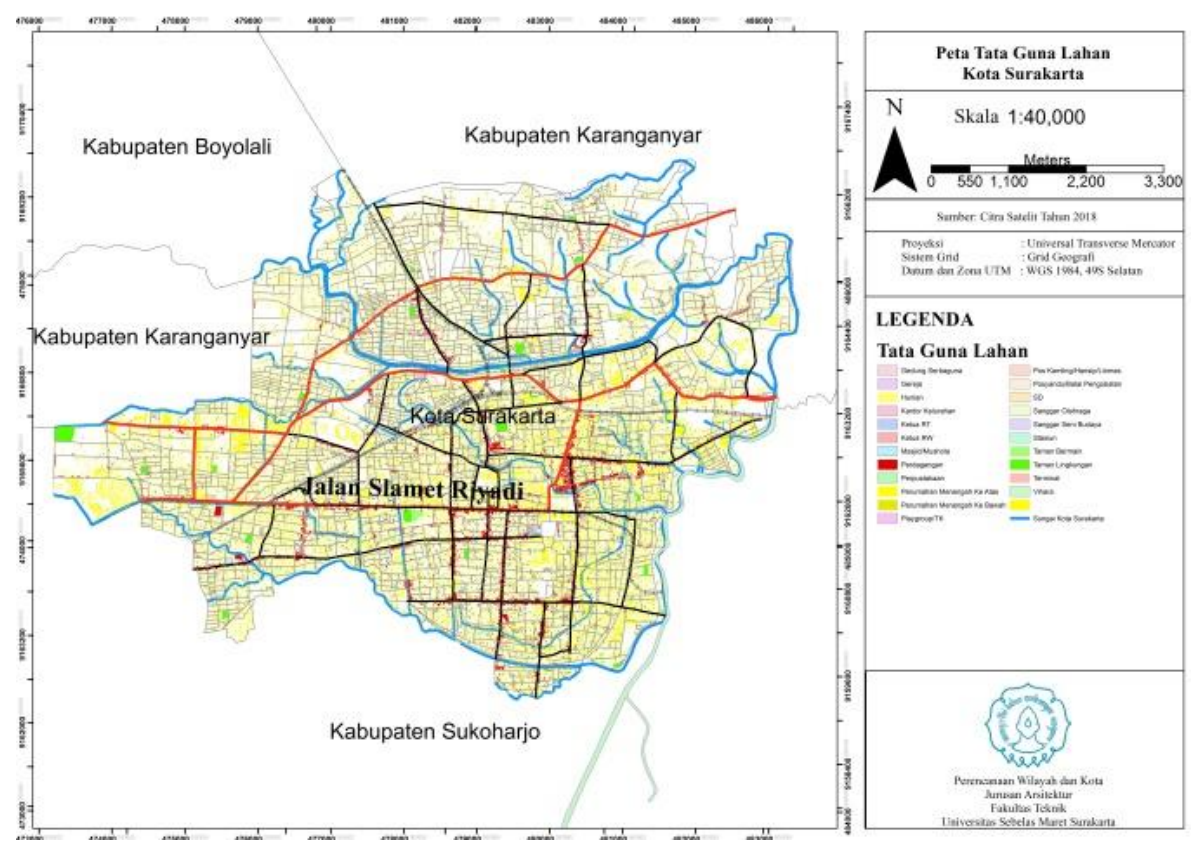

Sumber: BAPPEDA Kota Surakarta, 2018

Gambar 2. Peta Tata Guna Lahan Kota 


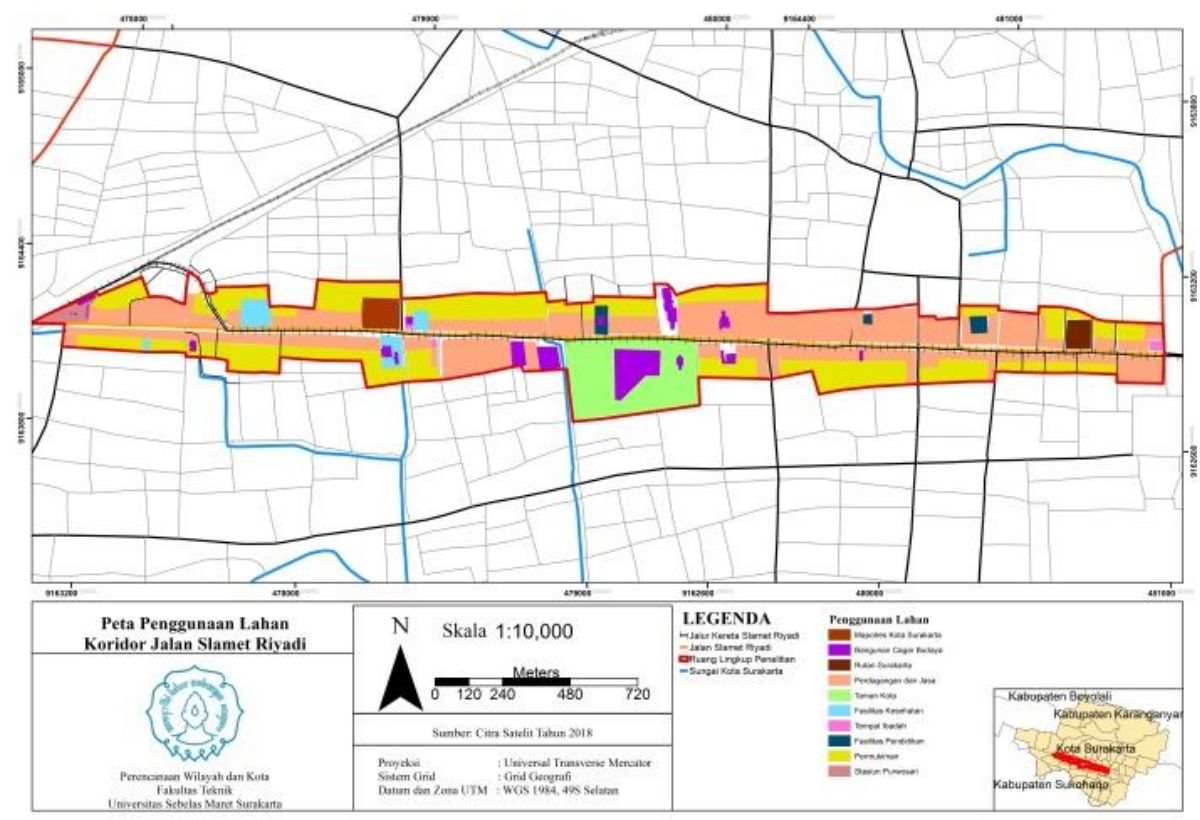

Gambar 3. Peta Penggunaan Lahan di Koridor Jalan Slamet Riyadi

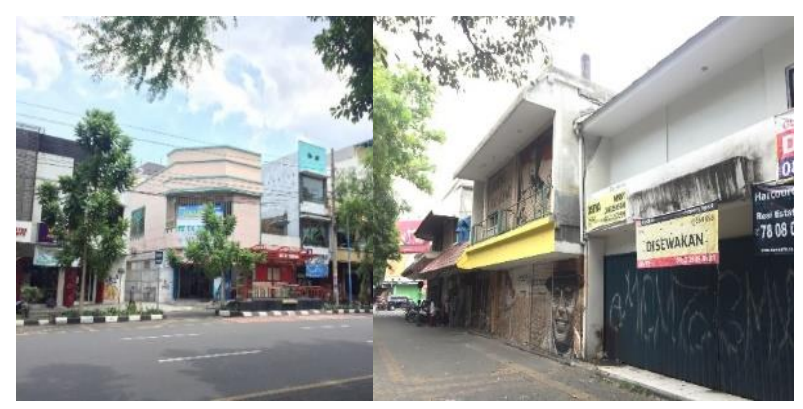

Gambar 4. Fasade Bangunan dengan Fungsi Usaha di Sepanjang Koridor Jalan Slamet Riyadi

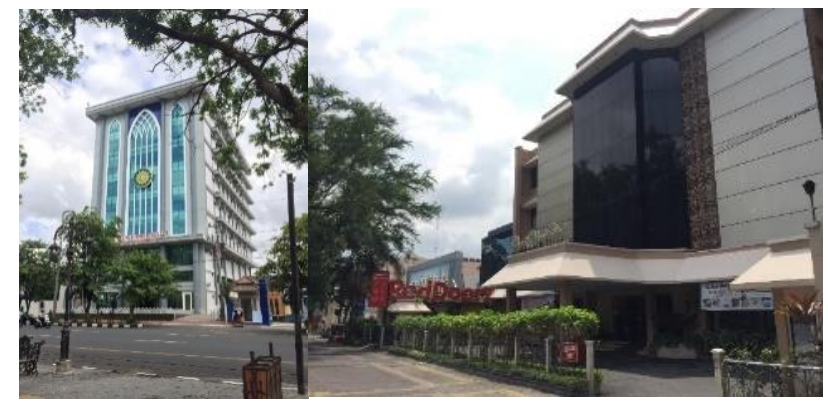

Gambar 5. Fasade Bangunan dengan Penggunaan Pelayanan Kesehatan dan Hotel di Sepanjang Koridor Jalan Slamet Riyadi

\subsection{KORIDOR JALAN SLAMET RIYADI DALAM PERKEMBANGAN KOTA SURAKARTA}

Sejarah terbentuknya kawasan Jalan Slamet Riyadi tidak terlepas dari perkembangan Kota Surakarta pada abad XVII. Pada awalnya Kota Surakarta merupakan kota yang berbasis sungai sebagai transportasi utamanya. Hal ini dibuktikan dengan pusat perdagangan dan pelabuhan yang berkembang di sepanjang jalur transportasi air. Juga didukung dengan lanskap Kota Surakarta yang dilintasi sungai yang menghubungkan daerah-daerah Mataram. Pusat pemerintahan pertama adalah Keraton Kasunanan Surakarta (1746) yang kemudian pada tahun 1957 kekuasaan pecah menjadi dua yaitu Keraton Kasunanan dan Keraton Mangkunegaran.

Dijelaskan bahwa pada tahun 1810, di bawah kepemimpinan Daendels, dibangun jalan yang membentang sepanjang Pulau Jawa, yaitu dari Anyer sampai Panarukan, sepanjang 1000 kilometer (Zaida, 2004). Dampak dari pembangunan jalan tersebut sangat besar terhadap perubahan perkembangan kota-kota baik yang dilalui ataupun yang tidak. Kota Surakarta tidak dilalui jalur jalan Anyer - Panarukan secara langsung, namun karena Kota Surakarta merupakan pusat pemerintahan kota kerajaan di Jawa maka dibangun jalan yang menghubungkannya dengan pusat pemerintahan kolonial di Jawa yang berada di Semarang. Jalan tersebut dibangun di atas sebuah sungai yang sangat lurus, yaitu Sungai Bathangan. Jalan tersebut sempat tiga kali berganti nama, pertama kali dibangun bernama Wilheminastraat, kemudian berubah menjadi Purwosariweg, dan terakhir bernama Jalan Slamet Riyadi. Saat ini jalan ini merupakan jalan utama di Kota Surakarta. Kemungkinan akibat dari penutupan sungai ini, maka air yang ada dialirkan melalui sungai yang dibangun menuju utara menuju Sungai Pepe. 
Pusat Kota kemudian berkembang di sekitar Jalan Slamet Riyadi yang terpusat di Keraton Kasunanan Surakarta. Pada tahun 1864 jalur transportasi kereta api juga mulai merambah Kota Surakarta yang menghubungkan Semarang - Kota Surakarta. Jalur kereta api ini juga merupakan jalur transportasi yang pertama yang ada di Indonesia berada berdampingan dengan Jalan Slamet Riyadi. Jalan ini juga berperan sebagai pembatas daerah kekuasaan antara Keraton Kasunanan dan Keraton Mangkunegaran, dimana daerah kekuasaan Keraton Kasunanan Surakarta mencakup wilayah bagian sebelah selatan Jalan Slamet Riyadi sedangkan daerah kekuasaan Keraton Mangkunegaran Surakarta sebagian besar berada di bagian utara Jalan Slamet Riyadi. Adapun kedua kerajaan tersebut sampai sekarang masih berkedudukan di Solo sebagai pusat kebudayaan. Perkembangan Kota Surakarta dapat dilihat pada Gambar 6.

\subsection{IDENTITAS KORIDOR JALAN SLAMET RIYADI}

Jalan Slamet Riyadi termasuk tipe jalan yaitu jalan satu arah (1-3/1) yang memanjang ke timur mulai dari Tugu Purwosari hingga Simpang Tiga Gladag. Pada segmen ruas simpang Stasiun Purwosari hingga Simpang Empat Gendengan terdapat ruang parkir di sisi utara jalan dengan pola parkir paralel sejajar jalan yang mengambil ruang di bahu jalan. Sedangkan di sisi selatan jalan terdapat kebijakan contra flow yang memanfaatkan satu lajur untuk kendaraan dari arah Gladag menuju Purwosari. Kebijakan ini diterapkan untuk mengantisipasi kemacetan lalu lintas sebagai dampak adanya proyek pembangunan overpass Manahan. Sebagai pembatas antara jalan dan jalur lambat maupun antara jalan dan citywalk, terdapat taman yang ditumbuhi pohon-pohon perdu besar yang rindang terlihat menutupi ruas jalan (lihat Gambar 7).

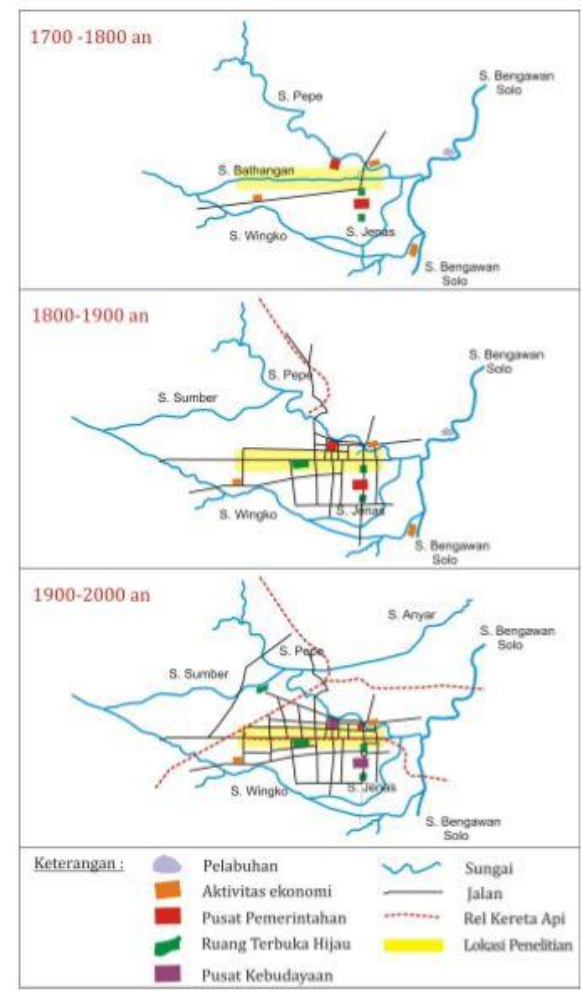

Sumber: Soedarmono, 2008

Gambar 6. Perkembangan Kota Surakarta

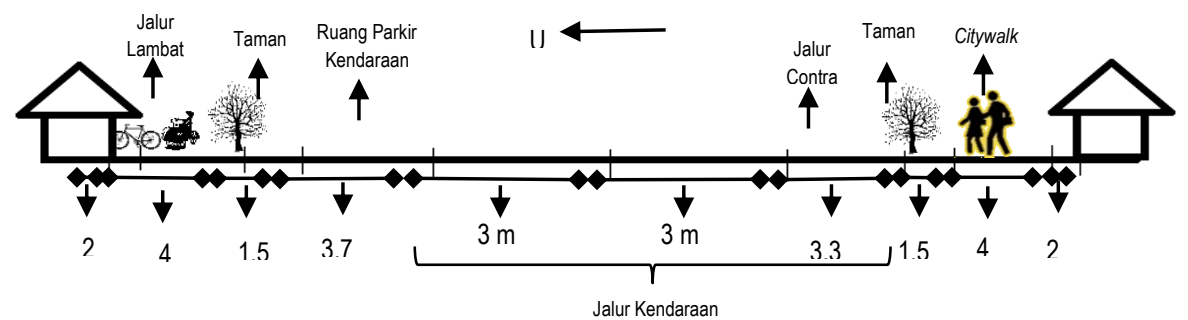

\section{Gambar 7. Ilustrasi Penampang Jalan pada Segmen Ruas Simpang Stasiun Purwosari hingga Simpang Empat Gendengan Koridor Jalan Slamet Riyadi}

Sedangkan pada Segmen Ruas Simpang Empat Gendengan hingga Simpang Gladag Koridor Jalan Slamet Riyadi terdapat ruang parkir di sisi utara jalan dengan pola parkir menyudut dengan sudut $60^{\circ}$ yang mengambil ruang di bahu jalan. Sedangkan di sisi selatan jalan terdapat rel kereta api aktif yang dilewati Kereta Uap Jaladara atau lebih dikenal dengan Sepur Kluthuk Jaladara dan Railbus Bathara Kresna menghubungkan Stasiun Purwosari dan Stasiun Solo Kota yang memanfaatkan satu lajur. Kereta yang melintas hanya 4 kali dalam sehari yakni pada pukul $06.00 \mathrm{WIB}$, pukul 08.00 WIB, pukul 09.30 WIB, dan pukul $13.30 \mathrm{WIB}$, sehingga rel tetap bisa dilalui kendaraan apabila tidak ada kereta yang melintas. Jalan Slamet Riyadi merupakan satu-satunya jalan besar di Indonesia yang memiliki rel kereta berada bersisian dan masih beroperasi hingga saat ini, sehingga pada jam-jam tertentu kendaraan yang lewat dapat berdampingan dengan kereta api yang melaju pelan membelah Kota Surakarta. Sebagai pembatas antara jalan dan jalur lambat maupun antara jalan dan citywalk, terdapat taman yang ditumbuhi pohon-pohon perdu besar yang rindang terlihat menutupi ruas jalan. Berikut adalah ilustrasi penampang jalan pada Segmen Ruas Simpang Empat Gendengan hingga Simpang Gladag Koridor Jalan Slamet Riyadi (lihat Gambar 8). 


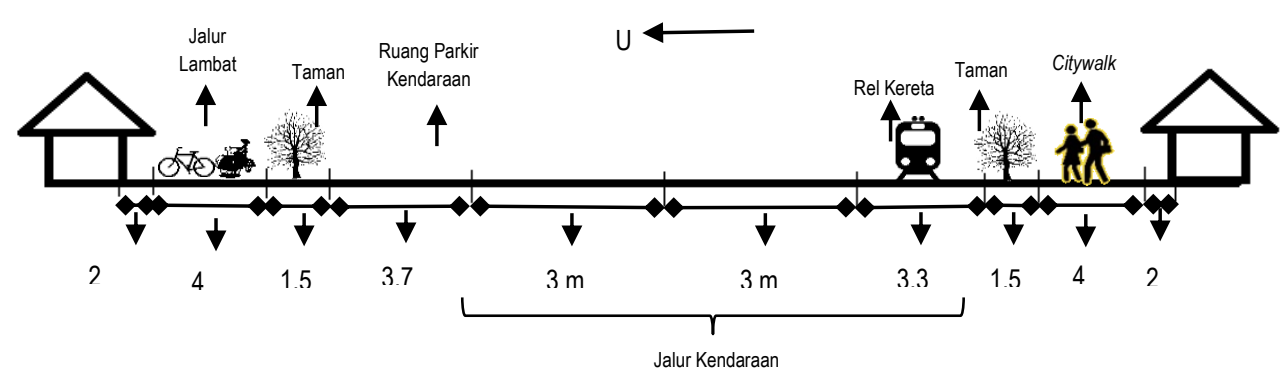

Gambar 8. Ilustrasi Penampang Jalan pada Segmen Ruas Simpang Empat Gendengan hingga Simpang Gladag Koridor Jalan Slamet Riyadi

\subsection{KORIDOR JALAN SLAMET RIYADI SEBAGAI RUANG INTERAKSI SOSIAL KOTA SURAKARTA}

Koridor Jalan Slamet Riyadi tidak hanya berfungsi sebagai jalan sekaligus wadah interaksi sosial masyarakat Kota Surakarta. Hal ini sejalan dengan pendapat Kurokawa yang menyebutkan koridor berfungsi sebagai jalan sekaligus wadah berinteraksi (Kurokawa, 1997). Juga didukung pernyataan bahwa suatu koridor tidak sekedar ruang sirkulasi, namun lebih jauh merupakan ruang aktivitas masyarakat (Project for Public Spaces, 2008). Kondisi interaksi sosial di Koridor Jalan Slamet Riyadi meliputi aktivitas ekonomi, sosial, dan budaya masyarakat, serta pelaku dan pihak yang terlibat dalam aktivitas tersebut. Menurut Gehl \& Gemzoe, aktifitas dalam ruang publik kota dibagi dalam dua kategori meliputi (Gehl \& Gemzoe, 1996): a) event dalam skala kecil; dan b) event dalam skala yang lebih besar. Di Koridor Jalan Slamet Riyadi, event dalam skala kecil berupa Solo Car Free Day yang termasuk aktivitas mingguan dan event dalam skala yang lebih besar berupa event-event kebudayaan yang termasuk dalam Kalender Event Tahunan Kota Solo dengan penjabaran sebagai berikut.

\subsubsection{AKTIVITAS MINGGUAN}

Adapun untuk aktivitas mingguan di Koridor Jalan Slamet Riyadi yaitu digelar agenda Solo Car Free Day (CFD) pada setiap Hari Minggu mulai dari Simpang Purwosari hingga Simpang Tiga Gladag pukul 05.00 WIB sampai 09.00 WIB. Para pengendara kendaraan bermotor bisa melewati area Solo CFD melalui beberapa simpangan yang sudah ditentukan. Semisal Simpang Empat Gendengan, Simpang Empat Ngapeman, dan Simpang Empat Nonongan. Gelaran Solo CFD merupakan terobosan mengurangi polusi udara di Kota Surakarta dan sebagai sarana bagi masyarakat untuk berolahraga, kegiatan sosial, dan lainnya (lihat Gambar 9). Masyarakat juga bisa berwisata kuliner di sepanjang citywalk yang dimanfaatkan sebagai area berdagang para penjaja makanan dan minuman (lihat Gambar 11). Selain itu, berbagai hal menarik bisa ditemukan saat Solo CFD seperti event-event dadakan, pertunjukan musik, pertunjukan seni, senam dan sebagainya. Terdapat pula beberapa pelayanan masyarakat gratis program Pemerintah Kota Surakarta yang bisa dimanfaatkan oleh masyarakat, diantaranya: a) Layanan Paspor Keliling, oleh Kantor Imigrasi Kelas 1 Surakarta tepatnya di barat Simpang Tiga Sriwedari bertujuan untuk mempermudah pelayanan kepada masyarakat dalam pembuatan paspor baru maupun perpanjangan paspor; b) Layanan SIM Keliling, oleh Polrestra Kota Surakarta yang melayani perpanjangan SIM bertempat di Satlantas Kota Surakarta Jalan Slamet Riyadi dengan mengunakan mobil keliling; c) Layanan Samsat Keliling, oleh Samsat Surakarta yang melayani pembayaran pajak kendaraan bertempat di barat Simpang Tiga Sriwedari; d) Konsultasi dan Cek Paru-Paru Gratis diselenggarakan oleh Perhimpunan Dokter ParuParu Kota Surakarta berlokasi di depan RS DKT Slamet Riyadi; e) Sosialisasi serta Cek Makanan dan Obat Berbahaya Gratis diadakan oleh Loka Pengawas Obat dan Makanan Badan Pengawasan Obat dan Makanan (BPOM) Kota Surakarta berlokasi di Simpang Tiga Sriwedari; f) Konsultasi dan Cek Kesehatan Gratis diadakan oleh Ikatan Dokter Indonesia (IDI) Surakarta pada minggu ke-3 setiap bulan berlokasi di depan Bank BNI; dan g) Sosialisasi dan Konsultasi KB Gratis rutin digelar oleh Dinas Pengendalian Penduduk dan Keluarga Berencana (DPPKB) Kota Surakarta setiap bulannya pada minggu ke-3 berlokasi di depan sekolah MAN 1 Jalan Slamet Riyadi (lihat Gambar 10). 
Keunikan Solo CFD yang tidak dimiliki daerah lain yaitu keberadaan kereta Batara Kresna dan Sepur Kluthuk Jaladara sering terlihat mondar-mandir saat gelaran berlangsung dengan suara klakson yang memekakkan telinga sebagai tanda kereta tersebut akan datang (lihat Gambar 12). Mendengar suara klakson orang-orang yang semula berada di atas jalur kereta langsung minggir. Meski melaju di tengah kerumunan, tetapi kecepatan kereta sangat pelan rata-rata tidak lebih dari $20 \mathrm{~km} / \mathrm{jam}$. Selain suara klakson, terdapat pula sejumlah petugas yang berjaga. Warga yang melihat keunikan tersebut langsung mengambil ponsel untuk mengabadikannya. Ada yang memotret, ada juga yang memvideokan. Bahkan tidak sedikit yang berswafoto di depan kereta tersebut.

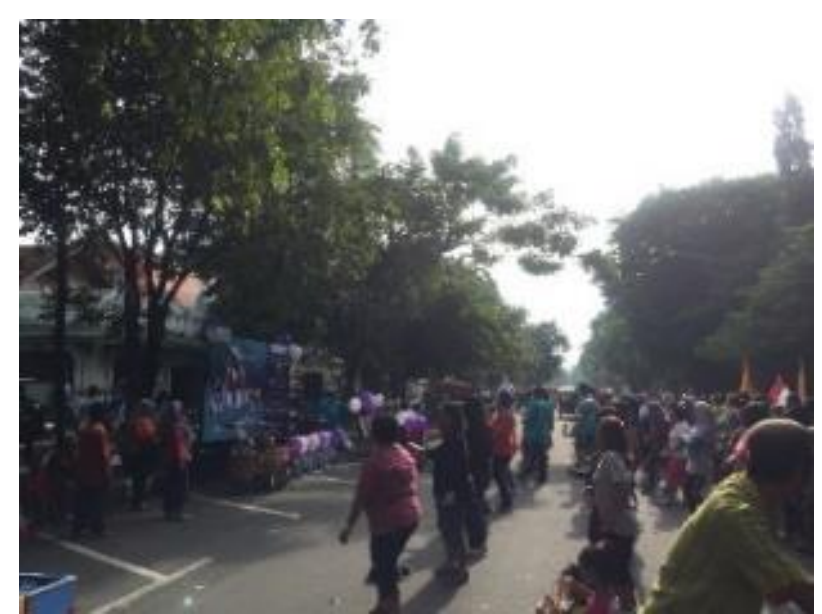

Gambar 9. Aktivitas Senam saat CFD di Jalan Slamet Riyadi

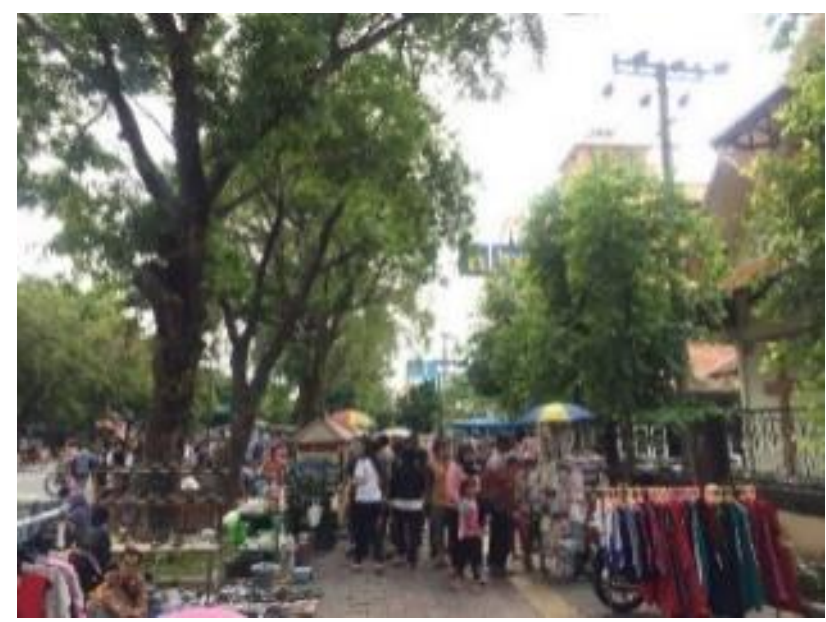

Gambar 11. Pemanfaatan Citywalk untuk Berjualan saat CFD

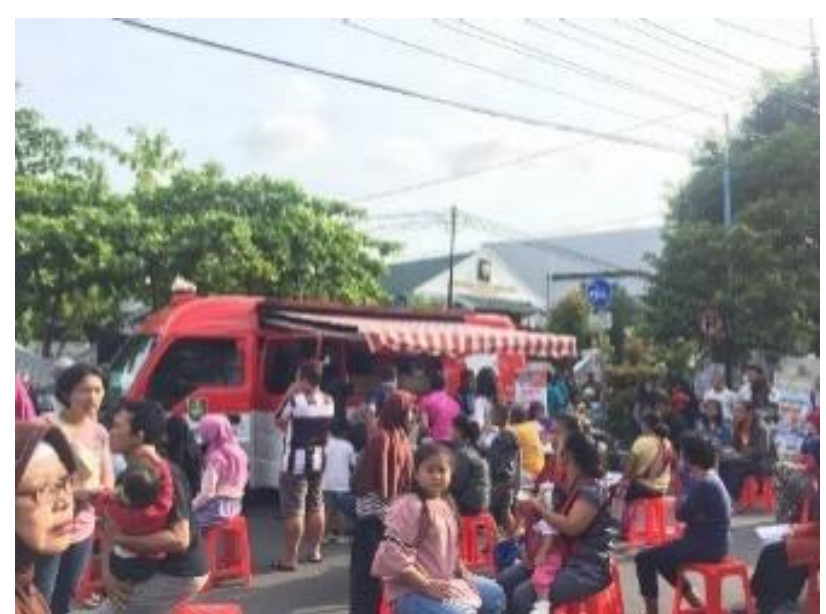

Gambar 10. Mobil Pelayanan Masyarakat saat CFD

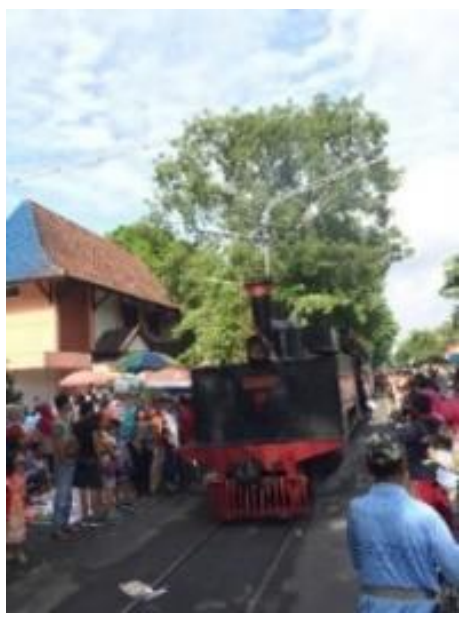

Gambar 12. Sepur Kluthuk Jaladara Melintas saat CFD

\subsubsection{AKTIVITAS TAHUNAN}

Kota Surakarta merupakan kota yang unik dengan banyak warisan budaya dan keramahtamahan. Selain itu, Kota Surakarta juga kota yang menarik dengan semangat festival, keberagaman kuliner, dan pusat perbelanjaan. Kota Surakarta memiliki program event budaya dan festival selama satu tahun penuh. Tentunya setiap acara yang digelar dalam kalender event Kota Solo biasanya bertepatan dengan peristiwa besar tertentu dan bertempat di beragam lokasi. Berdasarkan Kalender Event Kota Solo Tahun 2018 dan Kalender Event Kota Solo Tahun 2019 dari Dinas Pariwisata Kota Surakarta dapat diketahui beberapa event budaya dan festival Kota Surakarta yang setiap tahun selalu digelar di Koridor Jalan Slamet Riyadi, diantaranya: 


\section{a. Kirab Budaya HUT Kota Solo}

Setiap tanggal 17 Februari diperingati sebagai Hari Ulang Tahun (HUT) Kota Solo dan dimeriahkan dengan beragam rangkaian kegiatan diantaranya Festival Jenang Solo, Solo Great Sale, ziarah ke makam leluhur, serta dengan acara puncak yaitu Kirab Budaya Boyong Kedhaton dan Opera Adeging Kutha Sala (lihat Gambar 13). Kirab Budaya Boyong Kedhaton merupakan kirab budaya dengan konsep sejarah kelahiran Kota Solo. Pertunjukan ini dirangkai tanpa dialog, namun penonton akan dibantu dengan narasi dalam Bahasa Indonesia dan tembang-tembang sebagai pengiring adegan. Saat rangkaian kirab juga ditampilkan pertunjukan opera kolosal dengan lakon Adeging Kutha Sala. Sekaligus memeriahkan Festival Jenang Solo sebanyak 17 jenis jenang akan dikirab dalam acara tersebut. Kirab Boyong Kedhaton digelar bertepatan saat aktivitas CFD di Jalan Slamet Riyadi mulai dari simpang tiga Sriwedari menuju Balai Kota Solo.

\section{b. Solo Menari}

Setiap tanggal 29 April diperingati sebagai Hari Tari Dunia. Saat momen tersebut, Kota Solo turut memeriahkan peringatan Hari Tari Dunia dengan mengadakan event Solo Menari di sepanjang Jalan Slamet Riyadi dan digelar saat CFD mulai dari Simpang Empat Ngapeman hingga Simpang Gladag (lihat Gambar 14). Pada event Solo Menari 2018 diikuti sebanyak 5.035 penari hingga memecahkan Rekor Museum Rekor Dunia Indonesia (MURI) dengan perempuan penari Gambyong terbanyak. Penari tersebut berasal dari lingkungan sekolah, sanggar tari, wakil kelurahan, wakil kecamatan, universitas, dan warga umum. Saat event Solo Menari 2018 lalu, penari membawakan tiga Tari Gambyong. Tiga tarian tersebut meliputi Tari Gambyong 3WMP karya Nunuk Rahayu, Tari Gambyong Pareanom karya Ngaliman (Alm), dan Tari Pergaulan, dimana dalam tarian ini sang penari akan mengajak penonton yang hadir untuk turut beragabung menari.

\section{c. Peringatan HUT Hari Bebas Kendaraan atau Car Free Day (CFD)}

Hari Bebas Kendaraan atau Car Free Day (CFD) di Kota Surakarta pertama kali diterapkan oleh Wali Kota saat itu, Joko Widodo pada 30 Mei 2010. Peringatan HUT Solo CFD diselenggarakan oleh Dinas Perhubungan Kota Surakarta di Jalan Slamet Riyadi. Peringatan HUT Solo CFD juga dimeriahkan melalui beragam rangkaian kegiatan, seperti kegiatan senam massal, cek kesehatan gratis, kegiatan donor darah, dan lainnya. Melalui perayaan tersebut diharapkan agar Solo CFD dapat terus dimanfaatkan warga dengan kegiatan olahraga, kuliner, dan kreativitas seni tanpa disusupi agenda politik.

\section{d. Solo Batik Carnival}

Solo Batik Carnival atau Festival Batik Solo merupakan event tahunan yang diadakan pada bulan Juni oleh Pemerintah Kota Surakarta dengan menggunakan batik sebagai bahan utama pembuatan kostum. Para peserta akan membuat kostum karnaval dengan tema-tema yang berbeda setiap tahunnya. Para peserta akan mengenakan kostumnya sendiri dan berjalan di atas catwalk yang berada di jalan Slamet Riyadi menyusuri Jalan Slamet Riyadi mulai dari Simpang Purwosari hingga ke Balai Kota. Para peserta terdiri dari banyak elemen masyarakat diantaranya mahasiswa/pelajar, dosen, seniman, ibu rumah tangga, hingga anak-anak.

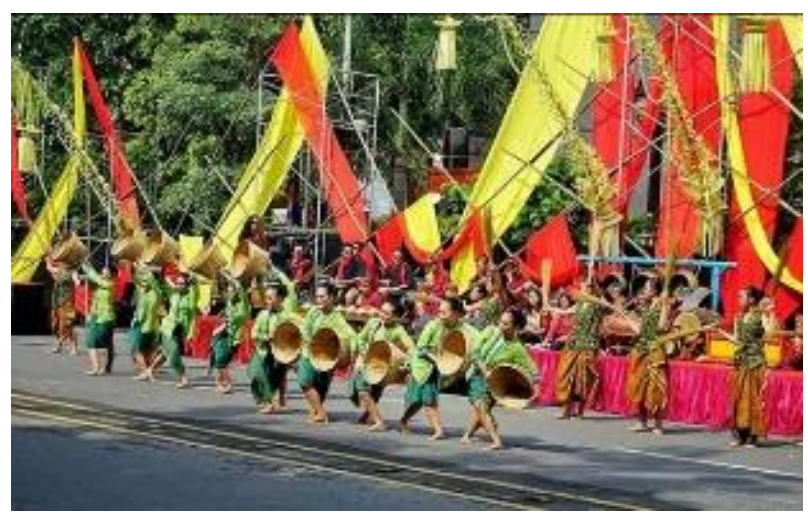

Gambar 13. Opera Kolosal Adeging Kutha Sala 2018

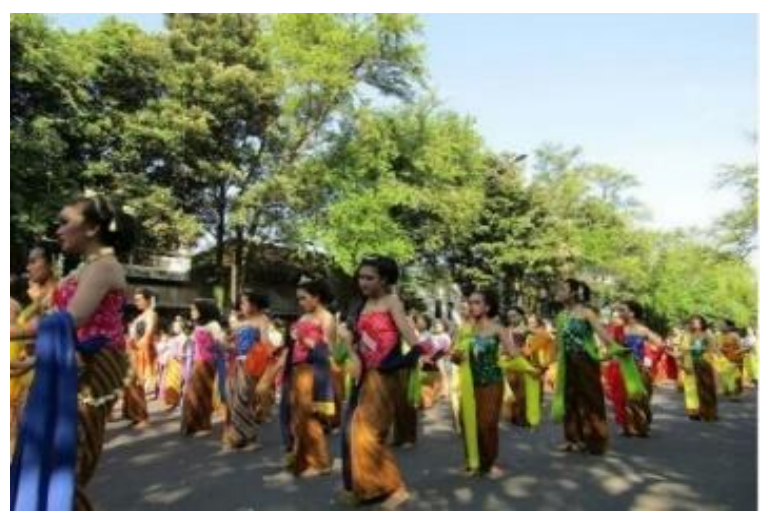

Gambar 14. Solo Menari 2018 


\section{e. Pawai Pembangunan}

Pawai Pembangunan diadakan guna memeriahkan HUT RI di Kota Surakarta. Pawai Pembangunan berlangsung sehari setelah puncak peringatan HUT RI diikuti oleh ratusan elemen masyarakat mulai dari Organisasi Perangkat Daerah, pegawai swasta, kalangan perbankan, pelajar dan mahasiswa, Paskibra Surakarta, marching band, TNI, Alutsista, Muspida, Kesenian, Komunitas serta beragam potensi kelurahan yang ikut membangun Kota Surakarta hingga perhotelan se-Solo Raya. Ribuan peserta tampil dalam dalam balutan busana dan ciri khasnya masing-masing. Pawai pembangunan dimulai dari Stadion Sriwedari hingga Jalan Jendral Sudirman pukul 13.00 - 16.00 WIB (lihat Gambar 15).

\section{f. Solo Open $10 \mathrm{~K}$}

Pemerintah Kota Surakarta menyelenggarakan lomba lari bertajuk Solo Open $10 \mathrm{~K}$ (lihat Gambar 16). Event ini merupakan lomba lari marathon sejauh $10 \mathrm{~km}$ yang digelar dalam rangka memperingati Hari Sumpah Pemuda yang jatuh setiap tanggal 28 Oktober. Kompetisi ini diikuti oleh peserta dari berbagai penjuru tanah air dan ada juga peserta yang berasal dari luar negeri. Rute yang dilewati dimulai dari Kantor DPRD Kota Surakarta melewati overpass Manahan - Jalan Slamet Riyadi - Beteng Trade Center - Pasar Gede hingga finish di Pendapi Agung Balai Kota Surakarta. Kompetisi ini dapat dijadikan awal untuk pembelajaran bagi Pemerintah Kota Surakarta dan Dinas Kepemudaan dan Olahraga pada khususnya dalam menyelenggarakan kompetisi olahraga tingkat nasional.

\section{g. Solo Car Free Night}

Solo Car Free Night merupakan event hari bebas kendaraan di malam hari untuk menyambut tahun baru. Seperti yang kemarin dilaksanakan yaitu Solo Car Free Night pada 31 Desember 2018. Jalan Slamet Riyadi bebas kendaraan mulai pukul 20.00 - 24.00 WIB. Oleh karena bebas dari kendaraan maka diadakan panggung hiburan untuk memeriahkan agenda tersebut. Kemeriahan terlihat sepanjang Jalan Slamet Riyadi hingga depan Balai Kota. Panggung hiburan bertempat di depan Loji Gandrung, Plaza Sriwedari, Kawasan Ngarsopuro, Kawasan Gladag, dan depan Balai Kota Surakarta yang diisi dengan atraksi seni dan tari tradisional, pagelaran musik jazz, karawitan, keroncong, perkusi, wayang dan musik religi (lihat Gambar 17).

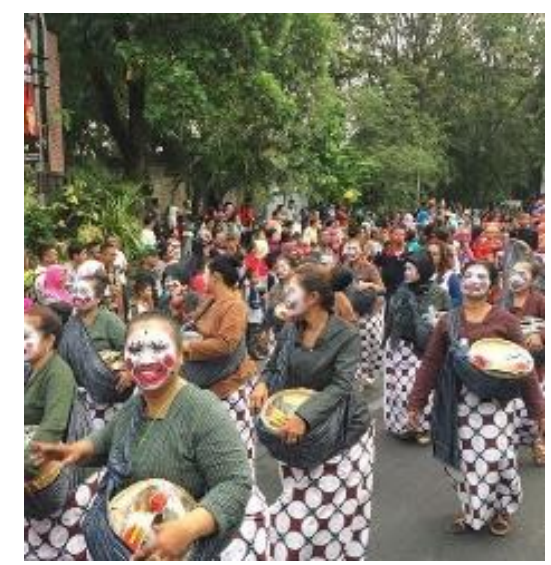

Gambar 15. Pawai Pembangunan 2018

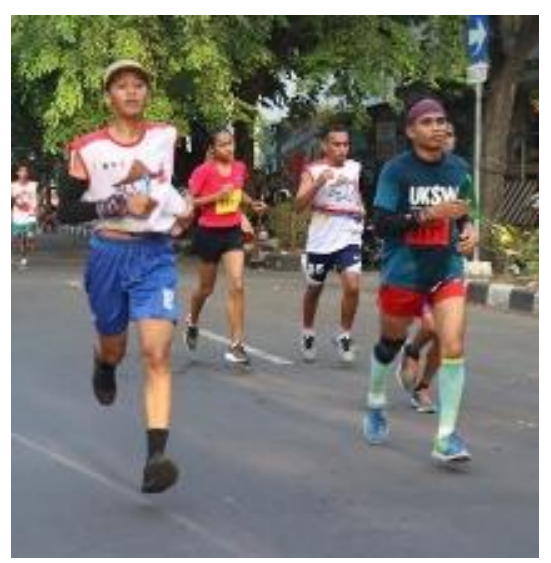

Gambar 16. Event Solo Open 10K 2018

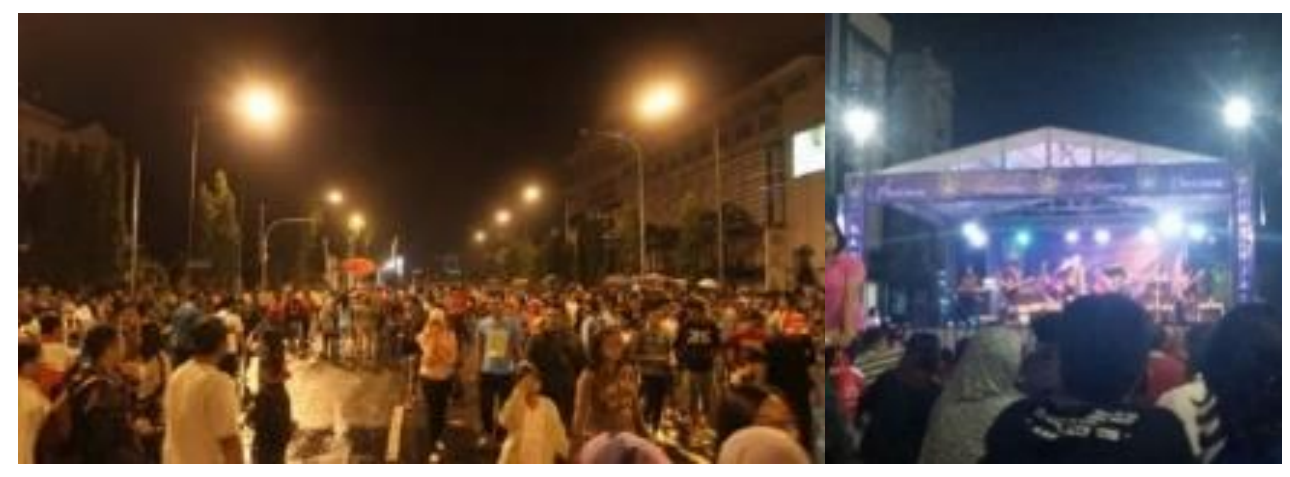

Gambar 17. Acara Solo Car Free Night 2018 


\subsection{KARAKTERISTIK KORIDOR JALAN SLAMET RIYADI SEBAGAI RUANG INTERAKSI SOSIAL KOTA SURAKARTA BERDASARKAN TEORI GOOD CITY FORM}

Suatu kota dapat dikatakan memiliki bentuk yang baik apabila memiliki lingkungan dengan karakteristik fisik (physical characteristic) dan karakteristik spasial (spatial characteristic) yang berbeda dengan kota lain. Karakteristik fisik kota paling mudah dikenali sebab dapat diamati secara langsung berkaitan dengan kenampakan suatu tempat; sedangkan karakteristik spasial kota berkaitan mengenai sebuah ruang yang dipengaruhi oleh suasana sehingga dapat dirasakan, memiliki peranan namun tidak terdefinisikan dengan jelas. Sama halnya pada Koridor Jalan Slamet Riyadi yang memiliki peranan penting bagi Kota Surakarta serta memiliki sejarah dan identitas sehingga mudah ditemui dan dikenali. Berdasarkan Teori Good City Form, Lynch menjelaskan bahwa suatu kota dapat dikatakan memiliki bentuk yang baik, apabila kota tersebut memenuhi kriteria vitality, sense, fit, accessibility, dan control (Lynch, 1981).

\subsubsection{VITALITY}

Sebagai ruang interaksi sosial perkotaan, Koridor Jalan Slamet Riyadi memiliki kemampuan untuk memenuhi kebutuhan vital warga kota. Hal ini terlihat pada peranan jalan ini sebagai jalan yang menghubungkan antara pintu masuk (Kawasan Stasiun Purwosari) hingga ke pusat Kota Surakarta (Kawasan Gladag) dengan keberagaman bangunan-bangunan yang berjejer di kedua sisi. Pusat bisnis Kota Surakarta terletak di sepanjang Jalan Slamet Riyadi seperti beberapa hotel, bank, perkantoran baik instansi pemerintahan maupun milik swasta, restoran, pusat perbelanjaan, gedung pertemuan, hingga ruko-ruko penyedia jasa dan barang. Selain itu, juga terdapat fasilitas umum lainnya seperti rumah sakit, gereja, Kompleks Mapolres Resor Kota Surakarta, dan Kawasan Taman Sriwedari sebagai salah satu tujuan wisata dan hiburan di Kota Surakarta. Jalan Slamet Riyadi memiliki luas keseluruhan mencapai 30 meter yang terbagi ke dalam beberapa jalur kendaraan. Jalur sebelah utara jalan ini digunakan sebagai jalur lambat yang biasa dilewati oleh pejalan kaki, sepeda, dan becak dengan lebar 4 meter. Jalur di tengah digunakan sebagai jalur yang dilewati kendaraan bermotor dengan luas keseluruhan mencapai 10 meter. Jalur kendaraan ini juga bersisihan dengan rel kereta api aktif di sebelah selatan. Serta jalur sebelah selatan Jalan Slamet Riyadi digunakan sebagai jalur untuk pejalan kaki mempunyai lebar 4 meter yang dikenal dengan nama Solo Citywalk. Pembatas antar jalur di Jalan Slamet Riyadi berupa taman di sebelah utara dan selatan mempunyai lebar 1,5 meter dengan kondisi eksisting ditanami oleh berbagai vegetasi, dari mulai ground cover hingga tanaman pohon tinggi sehingga terdapat kesan teduh dan nyaman saat melintas. Kondisi eksisting Koridor Jalan Slamet Riyadi ini sesuai dengan pendapat Zahnd bahwa koridor adalah jalan yang dibentuk oleh dua deretan massa (bangunan atau pohon) yang membentuk sebuah ruang untuk menghubungkan dua kawasan atau wilayah kota (Zahnd, 1999). Hal-hal tersebut membuat Jalan Slamet Riyadi menjadi jalan yang memiliki peran dan fungsi penting bagi Kota Surakarta, serta dengan keunikan kondisi eksisting yang ada memberi gambaran yang tidak terlupakan bagi siapa saja yang pernah melintas di jalan ini.

\subsubsection{SENSE}

Kota Surakarta dikenal sebagai kota dengan warisan kebudayaan yang beragam. Mengusung slogan 'Spirit of Java', Kota Surakarta juga kerap dianggap sebagai salah satu pusat kebudayaan Jawa dengan masih mempertahankan hingga kini. Terdapat banyak tempat menarik yang dapat dijadikan destinasi wisata budaya oleh para wisatawan yang berkunjung salah satunya berada di Koridor Jalan Slamet Riyadi. Jalan Slamet Riyadi memiliki peranan dalam mendukung Kota Surakarta sebagai kota budaya. Jalan ini sebagai penghubung menuju destinasi-destinasi wisata budaya di Kota Surakarta yang letaknya berdekatan satu sama lain. Ketika menyusuri Jalan Slamet Riyadi dari Stasiun Purwosari menuju ke timur (Kawasan Gladag), wisatawan akan menemukan beragam destinasi wisata budaya. Diantaranya: Kompleks Taman Sriwedari yang terdiri dari Gedung Wayang Orang Sriwedari, Museum Keris, dan Museum Radya Pustaka; Museum Batik Danar Hadi; Istana Mangkunegaran dan Pasar Antik Triwindu; dan Kampung Batik Kauman (lihat Gambar 18). 


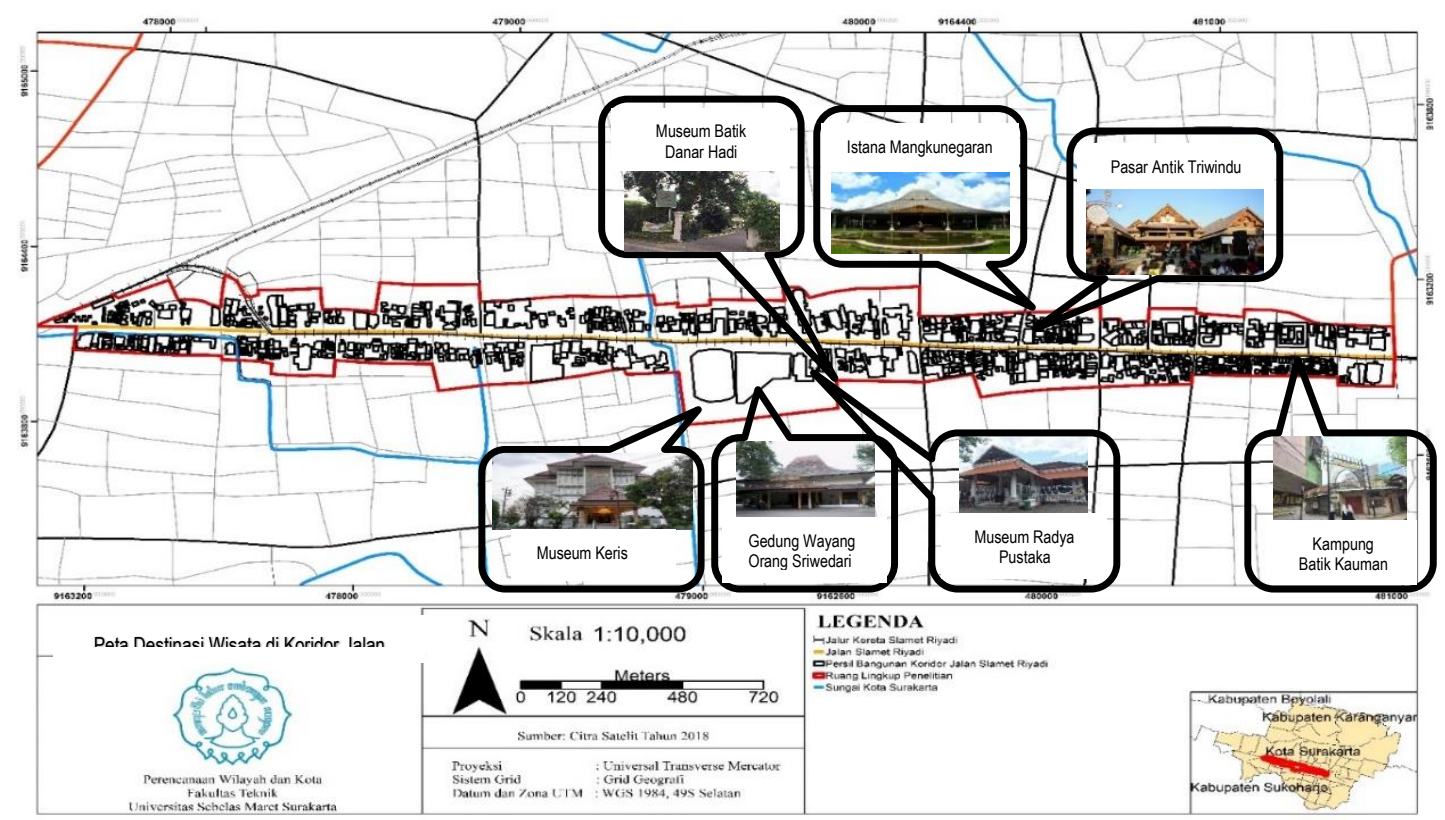

Gambar 18. Peta Destinasi Wisata di Koridor Jalan Slamet Riyadi

\subsubsection{FIT}

Dalam konteks sebagai ruang interaksi sosial perkotaan, kesesuaian Koridor Jalan Slamet Riyadi sudah sesuai. Jalan Slamet Riyadi akan dilakukan penutupan lalu lintas apabila terdapat event yang berlangsung, sehingga jalan dapat dimanfaatkan penuh sebagai ruang interaksi sosial Kota Surakarta. Sepanjang citywalk dimanfaatkan untuk berjualan makanan, minuman, dan kerajinan oleh para pedagang kaki lima yang hanya ada ketika event berlangsung. Sepanjang koridor ini terdiri dari deretan bangunan-bangunan dengan beragam penggunaan, dari keseluruhan luas wilayah ruang lingkup penelitian diketahui $66 \%$ atau seluas 719 ha merupakan lahan terbangun dengan persentase jenis penggunaan bangunan pada diagram berikut paling besar yaitu perdagangan sebesar $(68 \%)$ serta perkantoran dan perbankan sebesar (13\%) dapat dilihat dalam Gambar 19. Hal ini menunjukan bahwa di sepanjang Koridor Jalan Slamet Riyadi penggunaan lahan mayoritas berupa pertokoan, perdagangan, perkantoran, dan jasa. Keberadaan bangunan perdagangan dan jasa ini mendukung dan memudahkan pengunjung yang datang untuk berpartisipasi dalam event mingguan bahkan event tahunan yang digelar di Jalan Slamet Riyadi. Wisatawan cenderung memilih menginap di hotel yang dekat dengan lokasi event, serta terdapat beragam pilihan tempat makan dan wisata belanja di sepanjang Koridor Jalan Slamet Riyadi. Terdapat pula pilihan bank yang beragam, sehingga pengunjung event tidak perlu kesusahan apabila ingin mengambil uang. Selain itu, keberadaan jalur hijau di sepanjang sisinya berupa deretan pepohonan rindang yang memiliki bentuk daun memayungi jalan ini sehingga menimbulkan kesan nyaman dan memberikan kesejukan bagi masyarakat yang melaluinya.

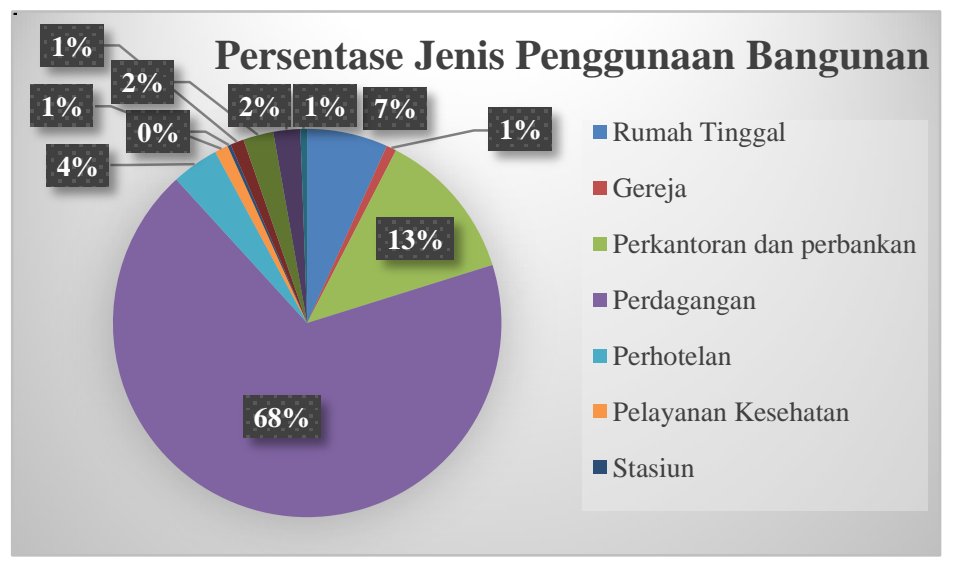

Gambar 19. Diagram Persentase Jenis Penggunaan Bangunan di Koridor Jalan Slamet Riyadi 


\subsubsection{ACCESSIBILITY}

Dalam konteks sebagai ruang interaksi sosial perkotaan, Koridor Jalan Slamet Riyadi dapat diakses dengan mudah dengan berbagai moda transportasi, seperti kendaraan pribadi, sepeda, becak, bis Batik Solo Trans (BST), serta berjalan kaki. BST merupakan salah satu moda transportasi umum di Kota Surakarta yang diluncurkan pada 1 September 2010 dan kini telah banyak membantu masyarakat sebagai alternatif transportasi dalam bepergian di dalam kota. Adapun BST yang melintas di Jalan Slamet Riyadi meliputi Koridor 1 dan Koridor 2. Koridor 1 mulai dari Terminal Palur dan pemberhentian terakhir adalah Bandara Adi Sumarmo dengan durasi waktu perjalanan rute ini sekitar 55 menit. Beroperasi setiap hari memiliki 38 pemberhentian, dengan 3 pemberhentian di antaranya terdapat di Jalan Slamet Riyadi yaitu Halte RS DKT, Halte Kasih Ibu, dan Halte Purwosari 2. Sebaliknya, Koridor 1 berangkat dari Bandara Adi Sumarmo dengan tujuan akhir Terminal Palur menempuh waktu perjalanan hampir sama sekitar 55 menit. Beroperasi setiap hari memiliki 42 pemberhentian, dengan 11 pemberhentian diantaranya terdapat di Jalan Slamet Riyadi yaitu Halte Purwosari 1, Halte PLN Solo, Halte RS Kasih lbu, Halte Satlantas, Halte Gendengan, Halte Sriwedari, Halte Ngapeman, Halte Timuran, Halte Pasar Pon, Halte Nonongan, dan Halte Gladag. Koridor 1 mulai beroperasi pukul 05.00 WIB hingga pukul 18.00 WIB. Sedangkan Koridor 2 mulai dari Terminal Palur dan pemberhentian terakhir adalah Terminal Kartosuro dengan durasi waktu perjalanan rute ini sekitar 54 menit. Beroperasi setiap hari memiliki 56 pemberhentian, dengan 3 pemberhentian diantaranya terdapat di Jalan Slamet Riyadi yaitu Halte RS DKT, Halte Kasih Ibu, dan Halte Purwosari. Sebaliknya, Koridor 2 berangkat dari Terminal Kartosuro dengan tujuan akhir Terminal Palur menempuh waktu perjalanan lebih cepat yaitu 48 menit. Beroperasi setiap hari memiliki 52 pemberhentian, dengan 4 pemberhentian diantaranya terdapat di Jalan Slamet Riyadi yaitu Halte Purwosari 1, Halte PLN Solo, Halte RS Kasih Ibu, dan Halte Satlantas. Koridor 2 mulai beroperasi pukul 05.30 WIB hingga pukul 18.02 WIB. Berikut peta rute BST Koridor 1 dan 2 dapat dilihat pada Gambar 20 dan 21.

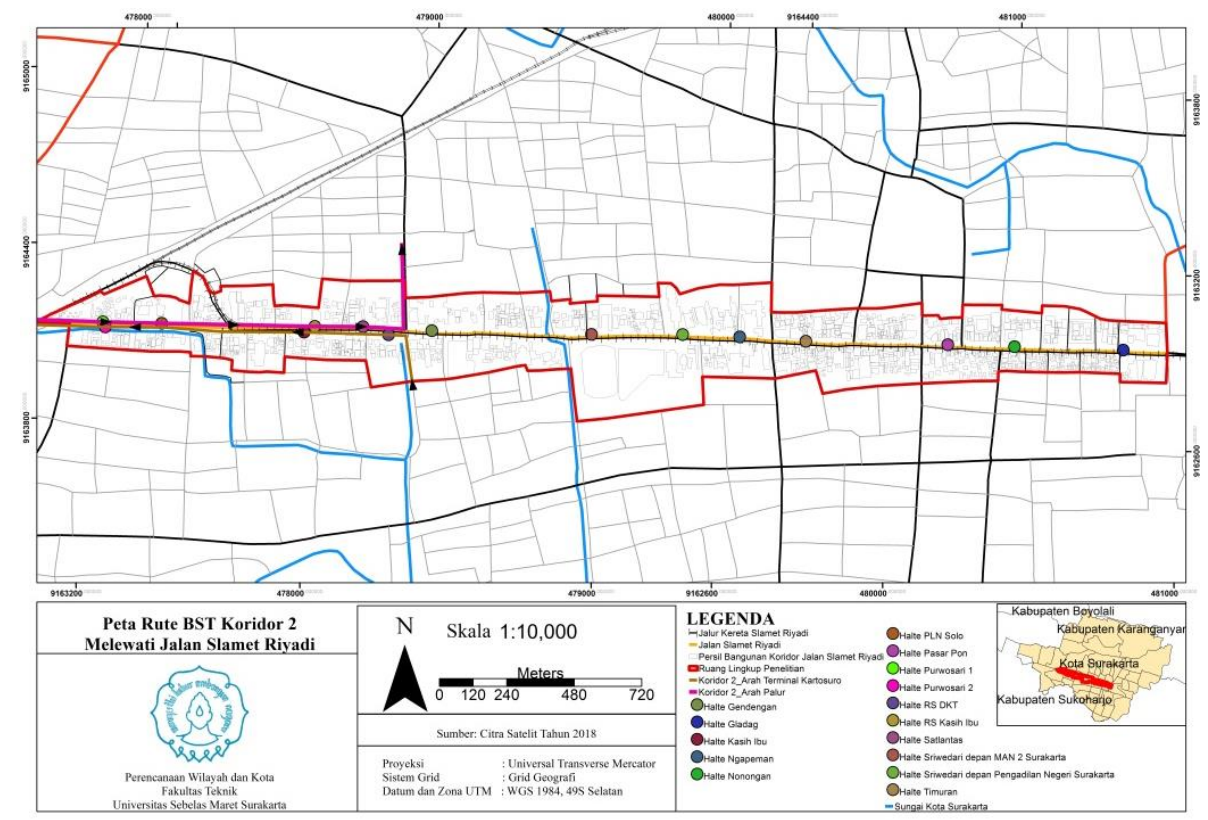

Gambar 20. Peta Rute BST Koridor 2 Melewati Jalan Slamet Riyadi

\subsubsection{CONTROL}

Kontrol diartikan sebagai masyarakat memiliki hak untuk melakukan aktivitas yang diinginkan saat event berlangsung mulai dari hanya menonton atraksi secara langsung hingga ikut serta selama pertunjukan. Selain itu, juga terdapat pihak yang bertanggung jawab melakukan penataan, penjagaan, dan mengawasi rangkaian acara saat suatu event berlangsung. Keseluruhan event dilakukan dengan adanya kerjasama dari berbagai Organisasi Perangkat Daerah (OPD) atau dinas-dinas terkait di Pemerintah Kota Surakarta. Seperti Dinas Perhubungan yang bertanggung jawab mengenai manajemen dan rekayasa arus lalu lintas terhadap kendaraan yang akan melintas di Jalan Slamet Riyadi dan ketersediaan kantong parkir kendaraan pengunjung event; Dinas Pariwisata yang bertanggung jawab mengenai penyelenggaraan dan pembinaan usaha akomodasi wisata, melakukan pemasaran atau promosi event yang akan berlangsung, serta pembinaan pelaku usaha ekonomi kreatif; Dinas Pekerjaan Umum dan Penatan Ruang bertanggung jawab atas kesiapan fasilitas-fasilitas pendukung event yang berada di Jalan Slamet Riyadi; Dinas Kebudayaan 
bertanggung jawab atas penyelenggaraan koordinasi di bidang kesenian, sejarah dan sastra, serta pelestarian budaya; Dinas Lingkungan Hidup bertanggung jawab pengelolaan kebersihan, sampah, dan pertamanan di sekitar lokasi; Dinas Koperasi dan Usaha Kecil Menengah bertanggung jawab atas keikutsertaan pelaku usaha mikro, kecil, dan menengah; Dinas Kesehatan bertanggung jawab atas ketersediaan tenaga medis dan fasilitas kesehatan yang berjaga saat event berlangsung; serta Dinas Kepemudaan dan Olahraga bertanggung jawab atas penyelenggaraan event di bidang kepemudaan dan olahraga seperti Solo Open $10 \mathrm{~K}$ dan Pawai Pembangunan. Selain itu, masyarakat juga memiliki kontrol penuh untuk melakukan aktivitas yang diinginkan saat event berlangsung mulai dari hanya menonton atraksi secara langsung hingga ikut serta selama pertunjukan.

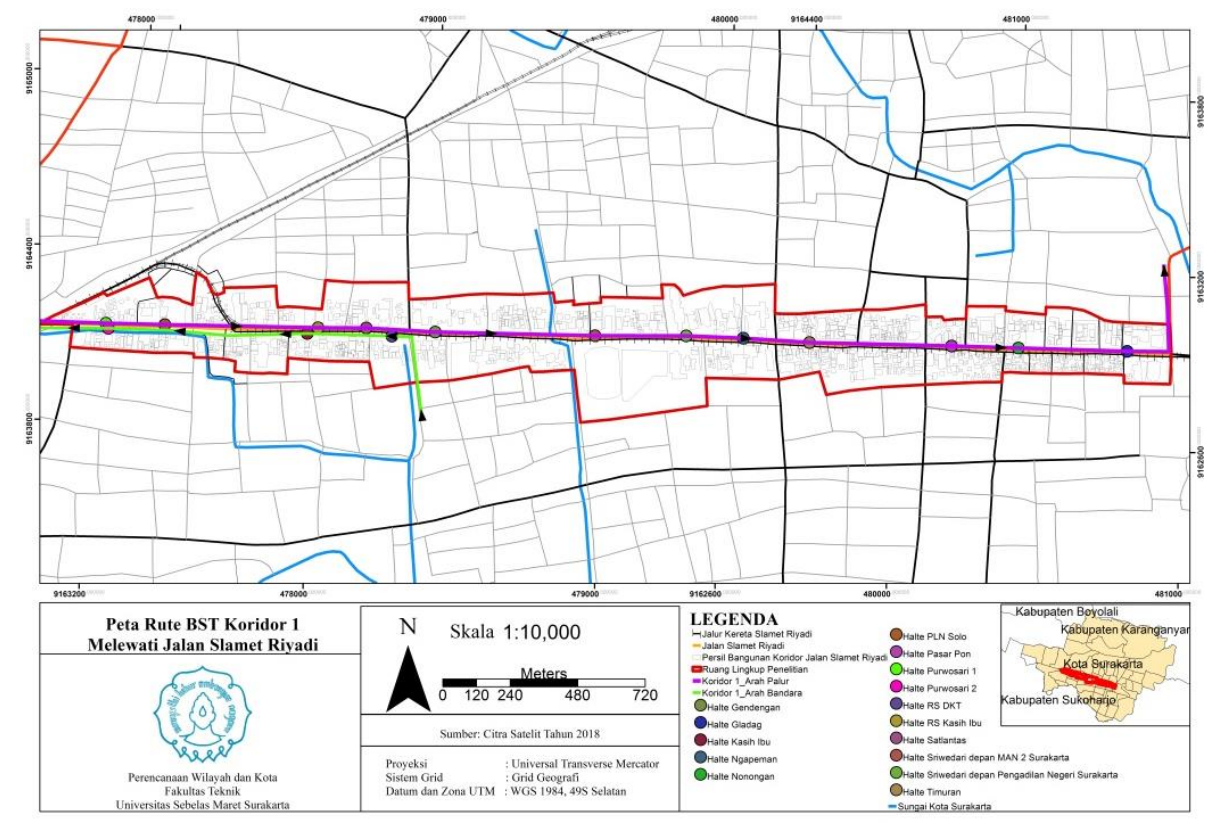

Gambar 21. Peta Rute BST Koridor 1 Melewati Jalan Slamet Riyadi

\section{KESIMPULAN}

Dari penjabaran tersebut dapat disimpulkan bahwa Koridor Jalan Slamet Riyadi memenuhi kriteria bentuk yang baik sebagai ruang interaksi Kota Surakarta berdasarkan Teori Good City Form, juga memiliki karakteristik fisik (physical characteristic) dan karakteristik spasial (spatial characteristic) yang berbeda dari jalan perkotaan lainnya. Karakteristik fisik yang sangat mudah dikenali dan menjadi identitas jalan ini yaitu jalan besar yang membelah pusat Kota Surakarta dengan pembagian jalur lalu lintas yang beragam mulai dari jalur lambat untuk becak dan sepeda, jalur kendaraan bermotor berdampingan dengan rel kereta api aktif, dan citywalk sebagai jalur pejalan kaki dengan dilengkapi deretan bangunan untuk perdagangan dan jasa serta pepohonan rindang. Sedangkan karakteristik spasial dari Koridor Jalan Slamet Riyadi yaitu jalan perkotaan yang memiliki nilai sejarah diantaranya sebagai pembatas daerah kekuasaan antara Keraton Kasunanan dan Keraton Mangkunegaran serta memiliki peranan sangat penting bagi Kota Surakarta selain sebagai penghubung menuju pusat Kota Surakarta dan saat ini juga menjadi wadah penyelenggaraan beragam aktivitas bagi masyarakat Kota Surakarta. Koridor jalan ini berfungsi sebagai ruang interaksi sosial di Kota Surakarta seperti Solo Car Free Day (CFD). Solo Batik Carnival, Solo Menari, Solo Run $10 \mathrm{~K}$, dan event tahunan Kota Surakarta lainnya.

\section{DAFTAR PUSTAKA}

(n.d.). P.2101 Koleksi Arsip Rekso Pustoko Pura Mangkunegaran

Agyeman, J., \& Zavetoski, S. (2015). Incomplete Streets: Processes, Practices, and Possibilities. Oxon: Routledge.

Bacon, E. N. (1967). Design of Cities. Thames and Hudson.

Bertolini, L. (2000). Planning in the Borderless City: A Conceptualisation and an Application to the Case of Station Area Redevelopment. Town Planning Review, 71, 455-475.

Bertolini, L., \& Dijst, M. (2003). Mobility Environments and Network Cities. Journal of Urban Desig, 8, 27-43.

Bishop, K. R. (1989). Designing Urban Corridors. Washington DC: American Planning Association. 
Brenner, N., Marcuse, P., \& Mayer, M. (2012). Cities for People, Not for Profit. Critical Urban Theory and the Right to the City. Oxon: Routledge.

Budiharjo, E., \& Sujarto, D. (2005). Kota Berkelanjutan. Bandung: PT Alumni.

Gehl, J., \& Gemzoe, L. (1996). Public Space - Public Life. Copenhagen: Department of Urban Design School of Architecture Royal Danish Academy of Fine Arts Denmark.

Hajer, M., \& Reijndorp, A. (2001). In Search of New Public Domain. Rotterdam: NAi Publishers.

Jacobs, A. B. (1993). Great Streets. Cambridge: MIT Press.

Jacobs, J. (1961). The Death and Life of Great American Cities. New York: Random House, Inc.

Kostof, S. (1992). The City Assembled: The Elements of Urban Form Through History. London: Thames and Hudson.

Krier, R. (1979). Urban Space. New York: Academy Editions.

Kurokawa, K. (1997). Each One a Hero: The Philosophy of Symbiosis. Tokyo, New York, London: Kodansha Int'l Ltd.

Linarwati, M., Fathoni , A., \& Minarsih, M. M. (2016). Studi Deskriptif Pelatihan dan Pengembangan Sumber Daya Manusia Serta Penggunaan Metode Behavioral Event Intreview dalam Merekrut Karyawan Baru di Bank Mega Cabang Kudus, Journal of Management, 2(2).

Lynch, K. (1981). Good City Form. Cambridge: MIT Press.

Mehta, V. (2013). The Street: A Quintessential Social Public Space. Oxon: Routledge.

Nas, P. (1979). Kota di Dunia Ketiga: Pengantar Sociologi Kota dalam Tiga Bagian. Jakarta: Bhratara Karya Aksara.

Nikolaeva, A. (2012). Designing Public Space for Mobility: Contestation, Negotiation and Experiment at Amsterdam Airport Schiphol. Tijdschrift voor Economische en Sociale Geografie, 103, 542-554.

Pontoh, N. K., \& Setiawan, I. (2008). Pengantar Perencanaan Kota. Bandung: Penerbit ITB.

Project for Public Spaces. (2008). Great Corridors, Great Communities. New York.

Shiraishi, T. (1997). Zaman Bergerak: Radikalisme Rakyat di Jawa (1912-1926). Jakarta: PT Pustaka Utama Grafiti.

Shirvani, H. (1985). The Urban Design Process. New York: Van Nostrand Reinhold.

Soedarmono. (2008). Babad Solo. Solo: Solo Heritage Community.

Sukandarrumidi. (2004). Metodologi Penelitian: Petunjuk Praktis untuk Peneliti Pemula. Yogyakarta: Gajah Mada University Press.

Sukmadinata, N. S. (2009). Metode Penelitian Pendidikan. Bandung: Rosdakarya.

Sumartono, L. (2003). Kajian Koridor Pandanaran Sebagai Linkage Kota di Semarang. Semarang: Universitas Diponegoro.

Trancik, R. (1986). Finding Lost Spaces: Theories of Urban Design. USA: John Willey and Sons.

Widayat. (2004). Metode Penelitian Pemasaran. Malang: CV Cahaya Press.

Zahnd, M. (1999). Perancangan Kota Secara Terpadu: Teori Perancangan Kota dan Penerapannya. Yogyakarta: Kanisius.

Zaida, S. (2004). Surakarta: Perkembangan Kota Ditinjau dari Perubahan Kondisi Sosial pada Bekas Ibukota Kerajaan di Jawa Skripsi. Bogor: Departemen Arsitektur Lanskap, Fakultas Pertanian, Institut Pertanian Bogor. 